\title{
Bacterial degradation of chlorophenols and their derivatives
}

\author{
Pankaj Kumar Arora and Hanhong Bae*
}

\begin{abstract}
Chlorophenols (CPs) and their derivatives are persistent environmental pollutants which are used in the manufacture of dyes, drugs, pesticides and other industrial products. CPs, which include monochlorophenols, polychlorophenols, chloronitrophenols, chloroaminophenols and chloromethylphenols, are highly toxic to living beings due to their carcinogenic, mutagenic and cytotoxic properties. Several physico-chemical and biological methods have been used for removal of CPs from the environment. Bacterial degradation has been considered a cost-effective and eco-friendly method of removing CPs from the environment. Several bacteria that use CPs as their sole carbon and energy sources have been isolated and characterized. Additionally, the metabolic pathways for degradation of CPs have been studied in bacteria and the genes and enzymes involved in the degradation of various CPs have been identified and characterized. This review describes the biochemical and genetic basis of the degradation of CPs and their derivatives.
\end{abstract}

Keywords: Chlorophenol, Environmental pollutants, Bacterial degradation, Biodegradation

\section{Introduction}

Chlorophenols (CPs) are aromatic ring structures containing at least one chlorine atom $(-\mathrm{Cl})$ and one hydroxyl $(-\mathrm{OH})$ group at the benzene rings. Five groups of CPs have been recognized on the basis of their chemical structures, monochlorophenols (MCPs), polychlorophenols (poly$\mathrm{CPs}$ ), chloronitrophenols (CNPs), chloroaminophenols (CAPs) and chloromethylphenols (CMPs) (Figure 1). These compounds are widely used (i) as mothproofing agents, miticides, germicides, algicides, fungicides and wood preservatives [1], as well as (ii) for the synthesis of dyes and drugs [2].

CPs have been introduced into the environment via anthropogenic activities [3]. The major sources of contamination are industrial wastes, pesticides, herbicides, and complex chlorinated hydrocarbons [3]. People may be exposed to CPs by eating or drinking substances that contain them or through skin contact [4]. CPs and their derivatives are highly toxic to living beings due to their carcinogenic, mutagenic and cytotoxic properties [5]. The World Health Organization and the International Agency for Research on Cancers have characterized several poly-CPs as potential

\footnotetext{
* Correspondence: hanhongbae@ynu.ac.kr

School of Biotechnology, Yeungnam University, Gyeongsan 712-749,

Republic of Korea
}

human carcinogens [5]. Similarly, the United States Environmental Protection Agency has included several CPs in its list of priority pollutants.

Several conventional methods such as adsorption, ion exchange, liquid-liquid extraction, and chemical oxidation and advanced oxidation processes have been used for the removal of CPs from wastewater $[3,6]$. These methods are expensive and not eco-friendly due to the formation of hazardous compounds as by-products [3]. Conversely, bioremediation is an effective and ecofriendly method of removing CPs from the environment. Biodegradation of CPs has gained attention due to the complete mineralization of CPs by microorganisms in the environment.

Several reviews dealing with the degradation and toxicity of CPs and their derivatives have been published $[3,5,7,8]$; however, these reviews were focused on the biodegradation/toxicity of MCPs or poly-CPs or both. The present review describes the biochemical and genetic basis of bacterial degradation of CPs and their derivatives including MCPs, poly-CPs, CAPs, CNPs and CMPs. Both aerobic and anaerobic bacterial degradation of CPs are discussed. 
MONOCHLOROPHENOLS
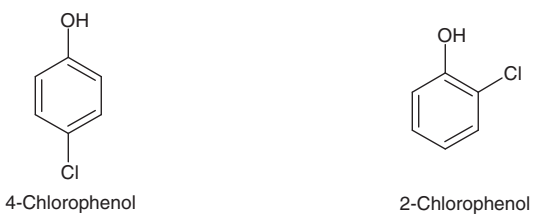

2-Chlorophenol<smiles>Oc1cccc(Cl)c1</smiles>

3-Chlorophenol

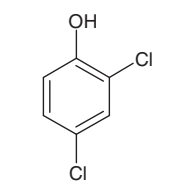

2,4-Dichlorophenol

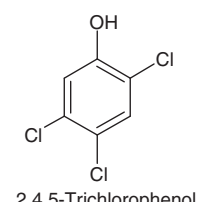

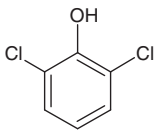

2,6-Dichlorophenol

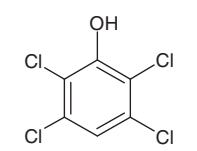

2,4,5,6-Tetrachlorophenol

CHLORONITROPHENOLS

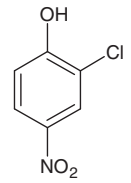

2-Chloro-4-nitrophenol<smiles>Nc1cc(Cl)ccc1O</smiles>

4-Chloro-2-aminophenol<smiles>Cc1cc(O)ccc1Cl</smiles>

4-Chloro-3-methylphenol

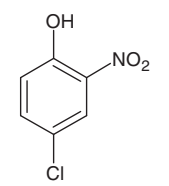

4-Chloro-2-nitrophenol

CHLOROAMINOPHENOLS<smiles>Nc1ccc(O)c(Cl)c1</smiles>

2-Chloro-4-aminophenol

CHLOROMETHYLPHENOLS<smiles>Cc1cc(Cl)ccc1O</smiles>

4-Chloro-2-methylpheno

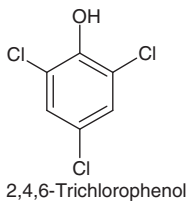<smiles>Oc1c(Cl)c(Cl)c(Cl)c(Cl)c1Cl</smiles>

Pentachlorophenol<smiles>O=[N+]([O-])c1ccc(Cl)c(O)c1</smiles>

2-Chloro-5-nitrophenol

Figure 1 Chemical structures of chlorophenols and their derivatives.

\section{Bacterial degradation of CPs}

Aerobic degradation of CPs and their derivatives have been extensively investigated in bacteria, and many bacteria with the ability to utilize CPs as their sole carbon and energy sources have been isolated [8]. One of the following mechanisms may be involved in the bacterial degradation of CPs and their derivatives: (i) monooxygenases may catalyze hydroxylation at the ortho-positions of the chlorophenolic rings, which results in the formation of chlorocatechols that may be degraded 
further via ortho- [9] or meta-cleavage [10,11] or hydroxylated prior to ring cleavage [12]; (ii) monooxygenases may catalyze the hydroxylation at para-positions of the chlorophenolic rings, resulting in the formation of chlorohydroquinones that may be degraded further via hydroxylation [12] or dehalogenation [13] prior to ring cleavage; (iii) the degradation of CNPs may be initiated via hydroxylation [14], reductive dehalogenation [15] or reduction of the nitro group [16], (iv) The degradation of ACPs may be initiated with the removal of ammonium ions by the enzyme deaminase followed by the ring cleavage [17] or the dehalogenation [18]. In this section, we describe the bacterial degradation pathways for MCPs, poly-CPs, CNPs, CAPs and CMPs.

\section{Bacterial degradation of MCPs}

MCPs, which are the simplest form of CPs, contain one chlorine atom at the phenolic rings. MCPs include 2chlorophenol (2CP), 3-chlorophenol (3CP), 4-chlorophenol (4CP), 3-chlorocatechol (3CC), 2-chlorocatechol (2CC) and 4-chlorocatechol (4CC). Chlorocatechols (CCs) were detected as intermediate products of bacterial degradation of MCPs, chlorobenzoates, mono-chlorobiphenyls, 4chlorosalicylate and 5-chlorosalicylate [19-23]. In this section, we have described the bacterial degradation of $4 \mathrm{CP}$, $2 \mathrm{CP}$ and $3 \mathrm{CP}$.

\section{Bacterial degradation of $4 \mathrm{CP}$}

Many bacteria that utilize 4CP as their carbon and energy sources have been isolated, including Pseudomonas knackmussii B-13 (previously known as Pseudomonas sp. B-13) [24,25], Ralstonia pickettii LD1 (previously known as Pseudomonas pickettii LD1) [26], Rhodococcus opacus 1G [27], Alcaligenes sp. A7-2 [28], Alcaligenes xylosoxidans JH1 [29], Arthrobacter ureafaciens CPR706 [30], Arthrobacter chlorophenolicus A6 [31], and Herbaspirillum chlorophenolicum CPW301 (previously known as Comamonas testosteroni CPW301) [32,33]. The bacterial degradation of 4CP occurs via either the CC pathway [34] or the hydroquinone (HQ) pathway [35]. In the CC pathway, $4 \mathrm{CP}$ is first converted to $4 \mathrm{CC}$ by a $4 \mathrm{CP}-2$-monooxygenase $(\mathrm{EC}=$ 1.14.13.-). Further degradation of $4 \mathrm{CC}$ then proceeds via the modified ortho-ring cleavage or meta-ring cleavage pathway [34]. In the modified ortho-cleavage pathway, 4CC is cleaved into 3-chloromuconate by a catechol-1,2-dioxygenase (EC 1.13.11.1) [7]. In the second step, 3chloromuconate is transformed to cis-dienelactone through the release of chloride ion by a chloromuconate cycloisomerase (EC 5.5.1.7) [Figure 2a]. In the next step, cis-dienelactone is converted to maleylacetate by a dienelactone hydrolase (EC 3.1.1.45) [7]. Maleylacetate is then reduced to 3-oxoadipate by a maleylacetate reductase (EC = 1.3.1.32). In the meta-cleavage pathway, $4 C C$ may be cleaved into a toxic compound, 5-chloro-2-hydoxymuconic semialdehyde (5C2HMS) by a catechol-2, 3-dioxygenase $(\mathrm{EC}=1.13 .11 .2)[7,36]$. In several cases, $5 \mathrm{C} 2 \mathrm{HMS}$ has been identified as a dead end product in the degradation pathway of 4CP [7,36]. However, the complete degradation of $5 \mathrm{C} 2 \mathrm{HMS}$ was observed in the 4CP degradation pathway in Comamonas testosteroni JH5 [10]. In strain JH4, 5C2HMS was converted to 5-chloro-2-hydroxypenta-2,4-dienoic acid, which was further degraded via intermediates of the TCA cycle [Figure 2b].

In addition to the modified-ortho or meta-ring cleavage pathway of $4 \mathrm{CC}$, there is another pathway for degradation of $4 \mathrm{CC}$, which is here designated as the 4CC-Benzenetriol (4CC-BT) pathway. In this pathway, $4 \mathrm{CC}$ is first hydroxylated to 1,2,4-benzenetriol (BT) through the release of chloride ion [12]. BT is then further degraded via ring cleavage and the formation of maleylacetate [12]. The 4CC-BT pathway was observed in the degradation of 4CP in A. chlorophenolicus A6 [12].

The 4CP degradation can also occur through the HQ pathway $[12,37]$. The first step of the HQ pathway is the formation of HQ through the release of chloride ion from $4 \mathrm{CP}$ by a $4 \mathrm{CP}-4$-monooxygenase [Figure $2 \mathrm{c}$ ]. In the next step, HQ is converted to BT, which is then cleaved into maleylacetate by a BT-dioxygenase [12]. A few bacterial strains degrade 4CP via two pathways. For example, $A$. chlorophenolicus A6 degrades 4CP via the HQ pathway as well as the 4CC-BT pathway [12].

\section{Bacterial degradation of $2 \mathrm{CP}$ and $3 \mathrm{CP}$}

Several 4CP-mineralizing bacteria including Ralstonia pickettii LD1 [26], Rhodococcus opacus 1G [27] and Alcaligenes xylosoxidans JH1 [29] also utilize 2CP and $3 \mathrm{CP}$ as their sole carbon and energy sources. Other 2CP-mineralizing bacteria include Alcaligenes sp. A7-2 [28] and Streptomyces rochei 303 [38]. The bacterial degradation of $2 \mathrm{CP}$ occurs via the formation of $3 \mathrm{CC}$, which is further degraded via the modified ortho-cleavage pathway or the meta-cleavage pathway [7,39]. In the modified ortho-cleavage pathway, 3CC is cleaved into 2chloro-cis,cis-muconate by a catchol-1,2-dioxygenase [7]. In the next step, a chloromuconate cycloisomerase catalyzes the conversion of 2-chloro-cis,cis-muconate to trans-dienelactone [7], which degrades further via formation of maleylacetate by dienelactone hydrolase [Figure 3a].

A new modified ortho-cleavage pathway of the $3 \mathrm{CC}$ was reported in Rhodococcus opacus $1 \mathrm{CP}$ that degraded $2 \mathrm{CP}$ via $3 C \mathrm{C}[40,41]$. The key enzymes of this pathway are chlorocatechol-1,2-dioxygenase, chloromuconate cycloisomerase (CMCI), chloromuconolactone isomerase (CMLI), and dienelactone hydrolase (DELH) [40]. Specifically, chlorocatechol-1,2-dioxygenase catalyzes the conversion of $3 \mathrm{CC}$ to 2-chloromuconate, while CMCI converts 2-chloromuconate into 5-chloromuconolactone, CMLI 

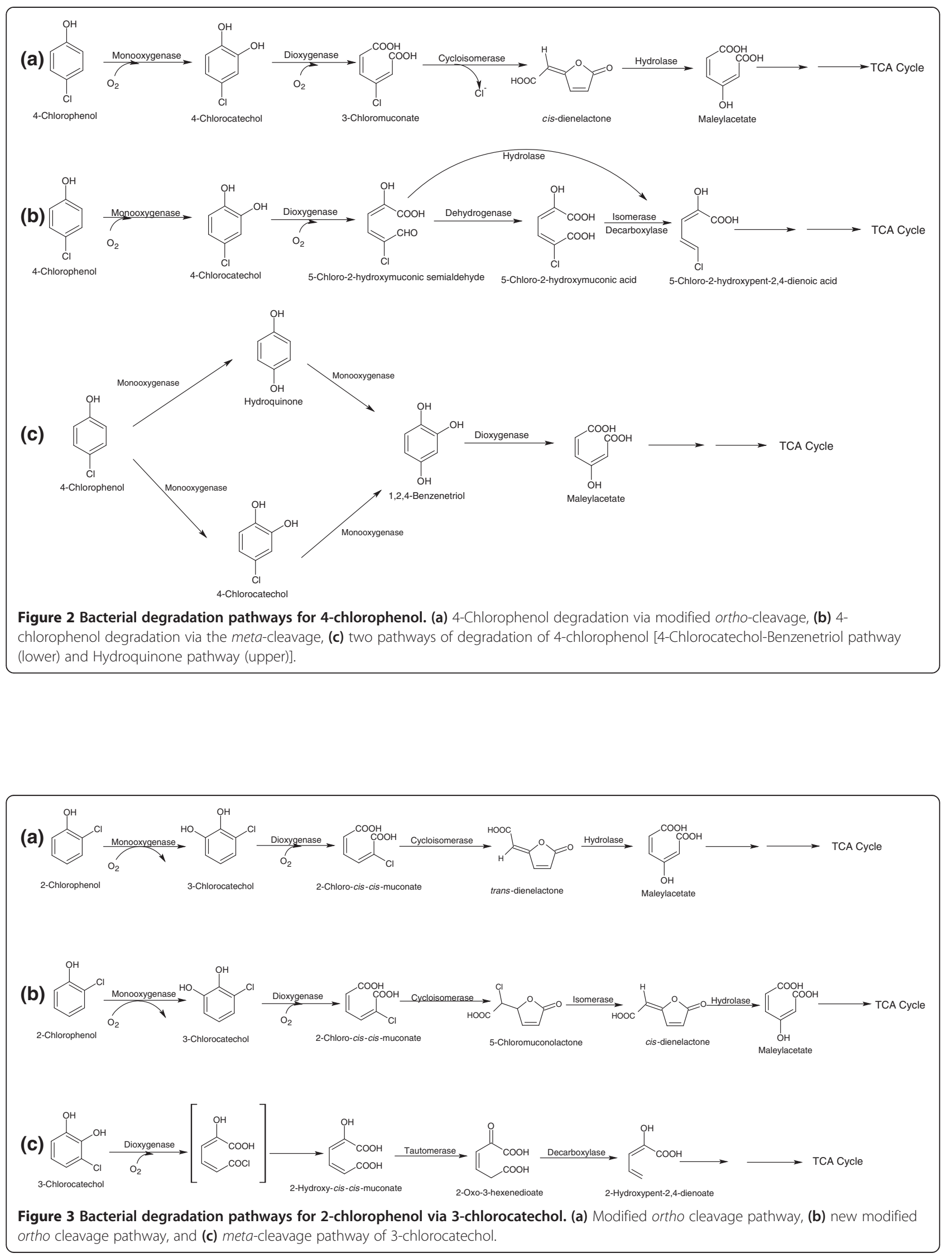
converts 5-chloromuconolactone into cis-dienelactone and DELH converts cis-dienelactone into maleylacetate, which is further degraded via the TCA cycle [Figure 3b].

In the meta-cleavage pathway, there are two possibilities for 3CC degradation: (i) formation of a dead end product $[39,42]$ and (ii) complete mineralization of 3CC [43]. In the first case, a suicide compound, 5-chloroformyl-2-hydroxypenta-2,4-dienoic acid, is formed due to the meta-cleavage of 3CC, which inactivates catechol-2,3-dioxygenase $(\mathrm{EC}=1.13 .11 .2)$, resulting in $3 \mathrm{CC}$ accumulation in the media. In the second case, bacteria may utilize $3 \mathrm{CC}$ completely. This type of pathway has been observed in the degradation of chloro-aromatics by Pseudomonas putida GJ31 [43]. In strain GJ31, 3CC was cleaved into 2-hydroxy-ciscis-muconate by a catechol-2,3-dioxygenase that was further degraded completely [43] [Figure 3c]. This pathway has been demonstrated in several other strains that are able to metabolize 3CC, including Pseudomonas sp. MG61, Pseudomonas fluorescens SK1 and Pseudomonas veronii 166 A [44].

The degradation of $3 \mathrm{CP}$ occurred either via the formation of $3 \mathrm{CC}$ or via the formation of $4 \mathrm{CC}$ that may be further degraded via the modified ortho-cleavage pathway or the meta-cleavage pathway [7,39].

\section{Bacterial degradation of poly-CPs}

poly-CPs such as dichlorophenols (DCPs), trichlorophenols (TCPs), tetrachlorophenols (TeCPs) and pentachlorophenol (PCP) are more recalcitrant to bacterial degradation than MCPs due to the presence of the two or more chlorine atoms at the phenolic rings. Here, we have described the degradation of 2,4-dichlorophenol (2,4-DCP), 2,4,6-trichlorophenol (2,4,6-TCP), 2,4,5-trichlorophenol (2,4,5-TCP) and PCP.

\section{Bacterial degradation of 2,4-DCP}

2,4-DCP is the first intermediate in the degradation pathway of a herbicide, 2,4-dichlorophenoxyacetic acid (2,4-D). Several bacteria that utilize 2,4-DCP as their sole source of carbon and energy have been isolated, including Pseudomonas sp. DP-4 [45], Rhodococcus opacus 1G [27], Rhodococcus erythropolis [46], and Pseudomonas sp. NCIB9340 [47]. Wang et al. [48] reported the removal of 2,4-DCP by the suspended and immobilized cells of Bacillus insolitus. They demonstrated that the immobilized cells showed faster degradation of lower concentrations of 2,4-DCP (10$50 \mathrm{mg} / \mathrm{l})$, whereas the high concentrations $(50-200 \mathrm{mg} / \mathrm{ml})$ were removed by immobilized and suspended cells at the same rate [48]. The bacterial degradation of 2,4-D is initiated by the formation of 2,4-DCP by the enzyme, 2,4-dichlorophenoxyacetate- $\alpha$-ketoglutarate dioxygenase ( $\mathrm{EC}=1.14 .11 .-)$ [49]. 2,4-DCP is further degraded via the formation of 3,5-dichlorocatechol by a 2,4-DCP-hydroxylase $[E C=1.14 .13 .20] \quad[50]$. In the third step, 3,5- dichlorocatechol is ortho-cleaved to 2,4-dichloromuconic acid by 3,5-dichlorocatechol dioxygenase ( $\mathrm{EC}=1.13 .11 .-)$ (Figure 4a). In the next step, 2,4-dichloromuconic acid isomerase $(\mathrm{EC}=5.2 .1 .10)$ catalyzes the conversion of 2,4 dichloromuconic acid to trans-2-chlorodienelactone via the removal of one chloro group, which is further converted to cis-2-chlorodienelactone by an isomerase that is subsequently degraded via formation of chloromaleylacetate by a hydroxylase [50]. The chloromaleylacetate is further degraded to maleylacetate by removal of the chloro group and then to 3-oxodipic acid by a maleylacetate reductase $(\mathrm{EC}=1.3 .1 .32)$. Koh et al. [51] reported that $o$-cresol grown cells of Cupriavidus necator JMP222 (a derivative of $C$. necator JMP134 that had lost plasmid pJP4) degraded 2,4DCP via a distal meta-cleavage pathway. In that process, 2,4-DCP is first oxidized to 3,5-dichlorocatechol, which is subsequently degraded via a distal meta-cleavage pathway through the formation of 2-hydroxy-3,5-dichloro-6-oxohexa-2,4-dienoic acid (Figure 4b).

\section{Bacterial degradation of 2,4,6-TCP}

Many bacteria that utilize 2,4,6-TCP as their sole carbon and energy source have been isolated and characterized including Azotobacter sp. Gp1 [52], Ralstonia pickettii [53], Cupriavidus necator [54,55], Nocardioides sp. K44 [56] and Novosphingobium lentum MT1 [57]. Bacterial degradation of 2,4,6-TCP was well-characterized in Cupriavidus necator JMP134 $[54,55]$. In the initial step of the TCP degradation, a reduced flavin adenine dinucleotide $\left(\mathrm{FADH}_{2}\right)$-utilizing monooxygenase catalyzes the conversion of 2,4,6-TCP to 6-chlorohydroxyquinol via the formation of 2,6dichlorohydroquinone [58]. 6-Chlorohydroxyquinol is then further cleaved to 2-chloromaleylacetate by 6chlorohydroxyquinol-1,2-dioxygenase, which is subsequently converted to maleylacetate by removal of the chloro group (Figure 5a).

\section{Bacterial degradation of 2,4,5-TCP}

Burkholderia phenoliruptrix AC1100 (previously known as B. cepacia) uses 2,4,5-TCP as the sole source of carbon and energy $[59,60]$. The first step in degradation of $2,4,5-\mathrm{TCP}$ involves conversion of $2,4,5$-TCP to 2,5 -dichloro- $p$-benzoquinone (DiCBQ) by $\mathrm{FADH}_{2}$-dependent-2,4,5-TCP-4monooxygenase (TftD) [EC $=1.14 .14 .-][60,61]$. DiCBQ is then reduced to 2,5-dichloro- $p$-hydroquinone (2,5-DiCHQ) by $\mathrm{NADH}$. In the next step, 2,5-DiCHQ is oxidized to 5chloro-2-hydroxy- $p$-benzoquinone by $\mathrm{TftD}$, which is then further reduced to 5-chloro-2-hydroxy- $p$-hydroquinone (CHHQ) [60,61]. Another enzyme, flavin reductase $\mathrm{TfC}$, supplies $\mathrm{FADH}_{2}$ as a co-substrate to $\mathrm{TftD}[60,61]$. In the next step, dehydrochlorinase $\mathrm{TftG}$ catalyzes the conversion of CHHQ to hydroxybenzoquinone, which is reduced to BT by hydroxylbenzoquinone reductase $(\mathrm{EC}=1.6 .5 .7)$ [62]. 


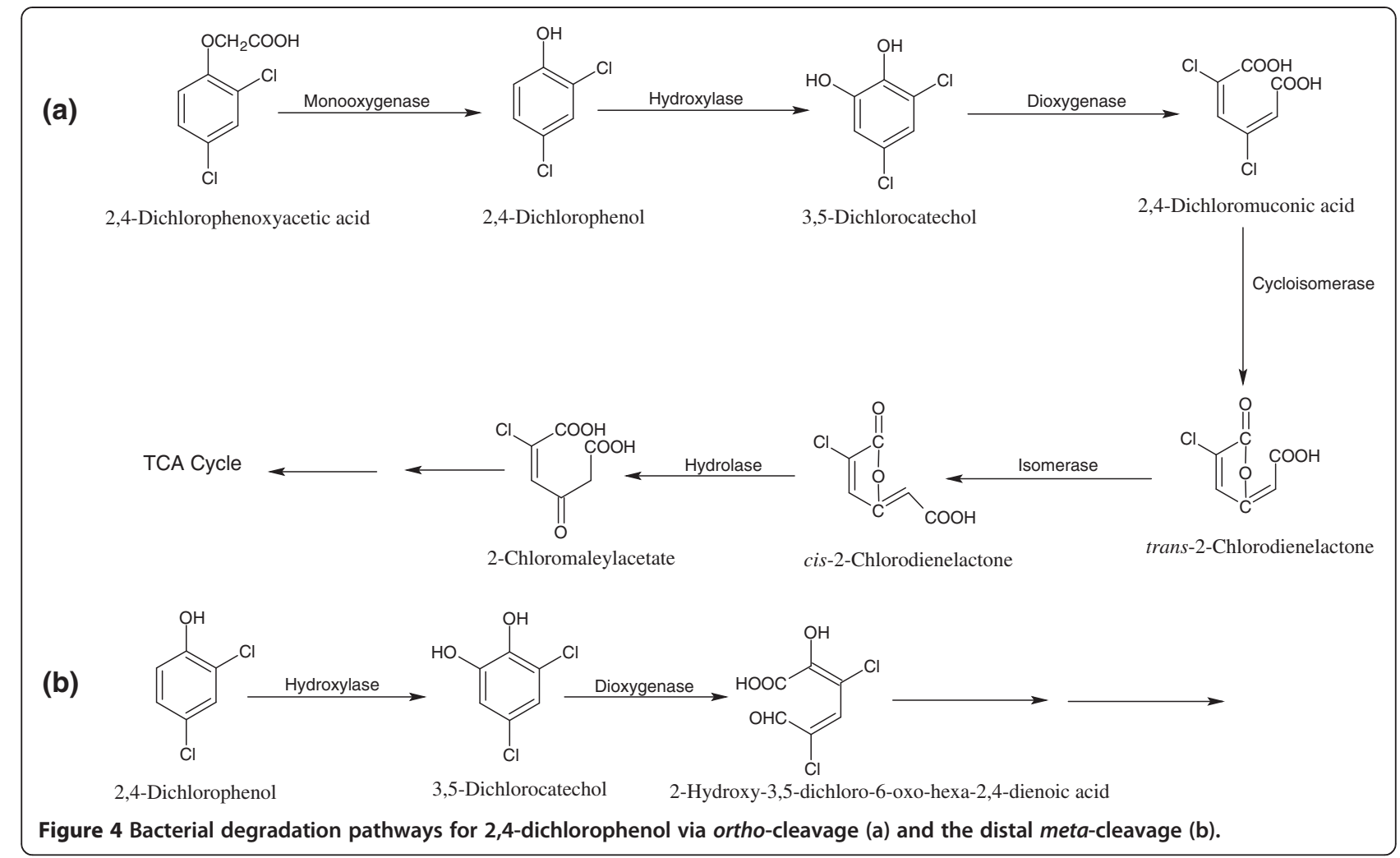

BT is subsequently converted to maleylacetate by BT-1,2- the para-position by either PCP-4-monooxygenase dioxygenase $(\mathrm{EC}=1.13 .11 .37$ ) (Figure $5 \mathrm{~b})$.

$(\mathrm{EC}=1.14 .13 .50) \quad$ [63-65] or cytochrome P-450 type enzyme [66,67] [Figure 6]. In Sphingomonas chlorophe-

\section{Bacterial degradation of PCP}

PCP degradation is initiated by the formation of tetranolicum L-1 (previously known as Sphingomonas chlorochlorohydroquinone (TeCHQ) due to hydroxylation at

phenolicum ATCC 39723), PCP-4-monooxygenase (PcpA) catalyzes the conversion of PCP to TeCHQ via

(a)<smiles>Oc1c(Cl)cc(Cl)cc1Cl</smiles><smiles>Oc1cc(Cl)c(O)c(Cl)c1</smiles>

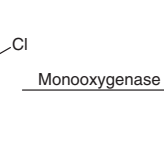

2,4,6-Trichlorophenol

2,6-Dichlorohydroquinone<smiles>CC1CCCCC1O</smiles><smiles>COC1=CC(=O)CC(C)C1O</smiles>
TCA Cycle

(b)

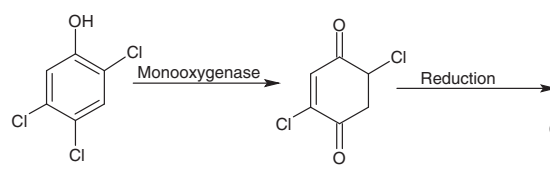

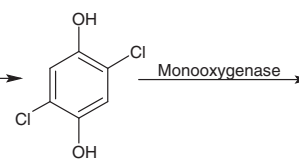<smiles>O=C1C=C(O)C(O)CC1=O</smiles>
Reduction<smiles>C[13C](O)c1cc(O)c(Cl)cc1O</smiles>

2,4,5-Trichloropheno

2,5-Dichloro- $p$-benzoquinone

2,5-Dichloro- $p$-hydroquinone

5-Chloro-2-hydroxy-p-benzoquinone 5-Chloro-2-hydroxy-p-hydroquinone Hydroxybenzoquinone

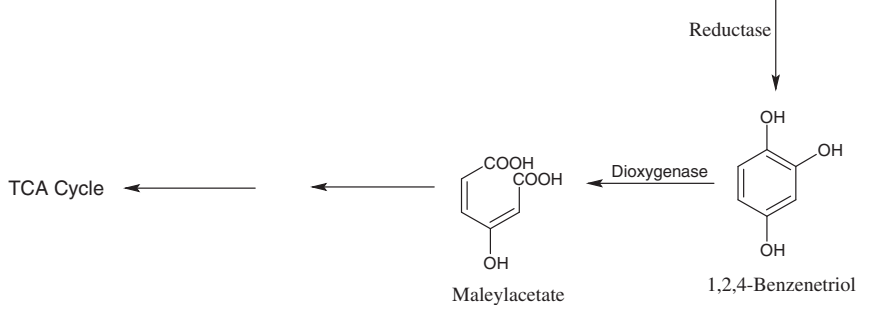

Figure 5 Bacterial degradation pathway for 2,4,6-trichlorophenol (a), and 2,4,5-trichlorophenol (b). 
(a)

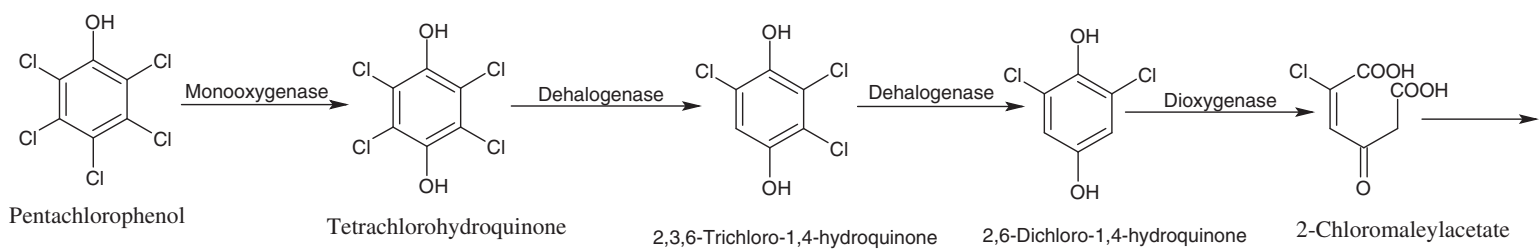

(b)

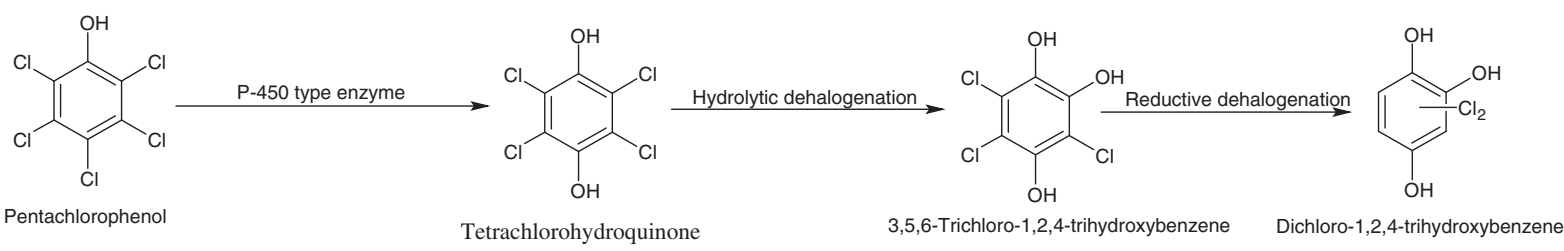

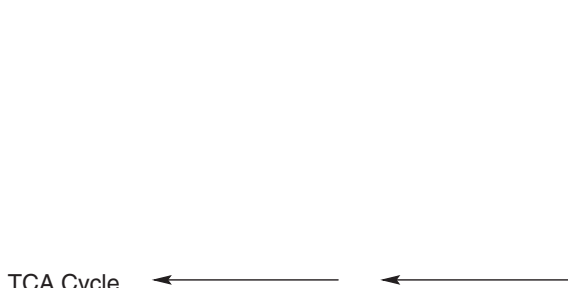

TCA Cycle

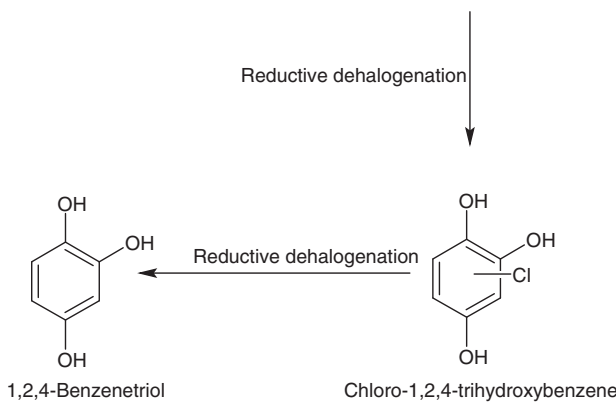

Figure 6 Bacterial degradation pathways for pentachlorophenol in Sphingomonas chlorophenolicum L-1 (a), and Mycobacterium strains (b).

the removal of chloride ions [63-65]. In the next step, TeCHQ is sequentially dehalogenated to 2,6-dichloro1,4-hydroquinone (2,6-DCHQ) by a TeCHQ-reductive dehalogenase $(E C=1.8 .99 .-)$. The further degradation of 2,6-DCHQ occurs via ring cleavage by the 2,6DCHQ-1,2-dioxygenase, leading to formation of 2chloromaleylacetate that is further degraded via the TCA cycle [63-65]. In Mycobacterium chlorophenolicum PCP1 and Mycobacterium fortuitum CG-2 (formerly Rhodoccocus strains), $\mathrm{PCP}$ is hydroxylated to TeCHQ by a membrane bound cytochrome P-450 type enzyme $[66,67]$. Subsequently, TeCHQ undergoes hydrolytic dehalogenation followed by reductive dehalogenation to form dichloro-1,2,4-trihydroxybenzene, which produces BT after two successive reductive dehalogenation [68].

\section{Bacterial degradation of CNPs}

CNPs are nitro derivatives of MCPs. Examples include 2chloro-4-nitropheol (2C4NP), 4-chloro-2-nitrophnol (4C2NP), 4-chloro-3-nitrophenol (4C3NP), 2-chloro-5-nitrophenol (2C5NP) and 2-chloro-3-nitrophenol (2C3NP). In this section, we have summarized the bacterial degradation of various CNPs.

The degradation of 2C4NP has been studied in Burkholderia sp. SJ98 [15], Burkholderia sp. RKJ 800 [14], Arthrobacter nitrophenolicus SJCon [69] and Rhodococcus imtechensis RKJ300 [70]. Pandey et al. [15] proposed a degradation pathway of 2C4NP in Burkholderia sp. SJ98 that utilized 2C4NP as the sole carbon, nitrogen and energy sources. The first step of the 2C4NP degradation in strain SJ98 involves the reductive dehalogenation of 2C4NP by 2C4NP-dehalogenase that leads to the formation of 4nitrophenol (4NP) [Figure 7a]. In the next step, 4NP is converted to 4-nitrocatechol and then to BT, which is further cleaved into maleylacetate by BT-1,2-dioxygenase. Maleylacetate is further degraded via the $\beta$-ketoadipic acid cycle [15]. Another pathway of the 2C4NP degradation was investigated in Rhodococcus imtechensis RKJ 300 [70] and Bukholderia sp. RKJ 800 [14]. In this pathway, 2C4NP is first transformed to chlorohydroquinone (CHQ) by 2C4NP-monooxygenase. $\mathrm{CHQ}$ is then dehalogenated to HQ by CHQ-dehalogenase [14]. In the next step, HQ is cleaved to $\gamma$-hydroxymuconic semialdehyde by HQ-1,2dioxygenase $(E C=1.13 .11 .66)$ [Figure $7 \mathrm{~b}$ ]. Arora and Jain [69] reported a new degradation pathway of 2C4NP in Arthrobacter nitrophenolius sp. SJCon. In strain SJCon, 2C4NP is first converted to CHQ and then further cleaved to maleylacetate by $\mathrm{CHQ}$-dioxygenase [Figure 7c].

The first report of the $4 \mathrm{C} 2 \mathrm{NP}$ degradation was documented in 1988 with construction of a genetically engineered bacterium, Pseudomonas sp. N31, which utilizes 4C2NP as a sole carbon, nitrogen and energy source [71]. The constructed strain degrades $4 \mathrm{C} 2 \mathrm{NP}$ via the formation of $4 \mathrm{CC}$ and the release of chloride and nitrite 


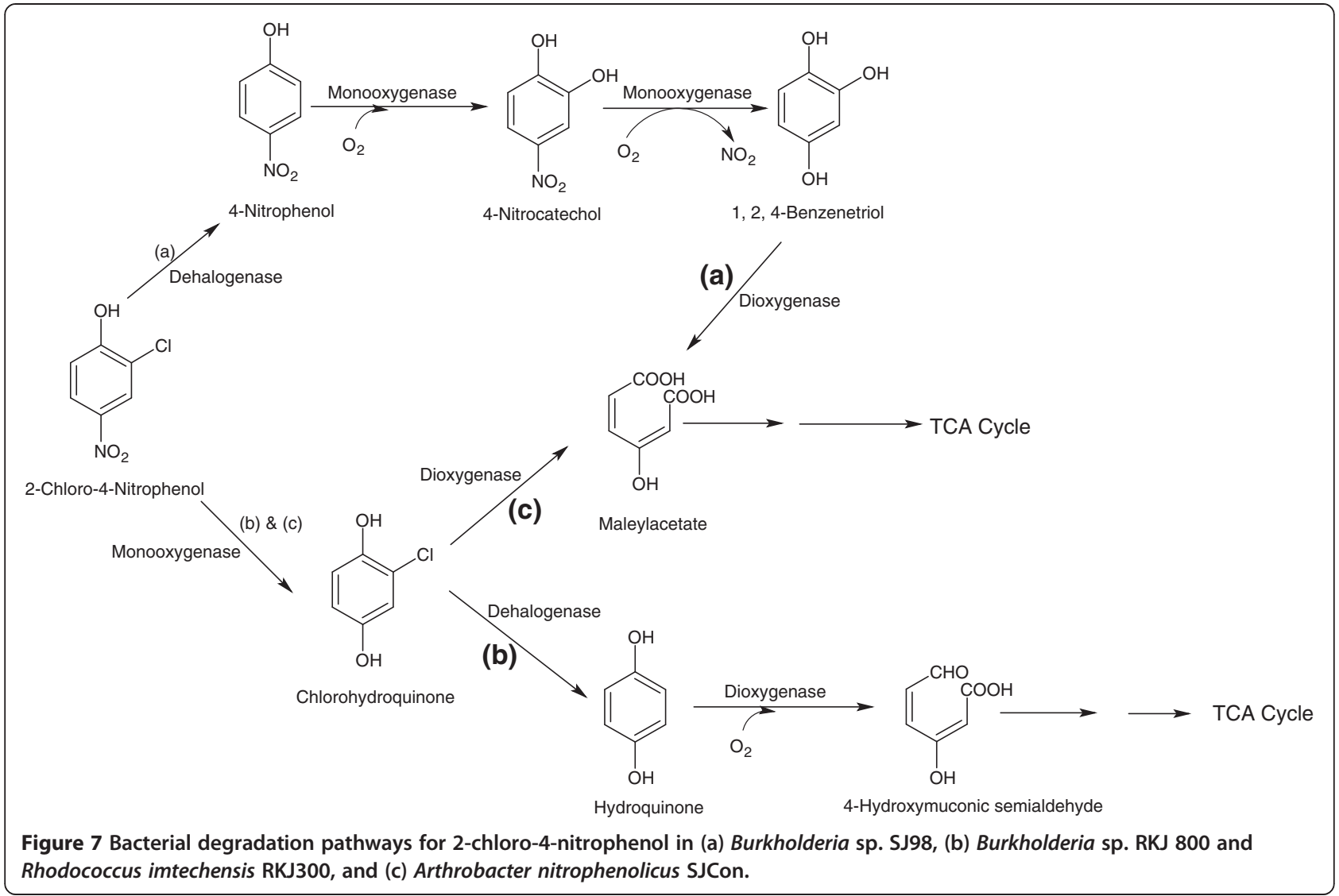

ions [Figure 8]. Beunink and Rehm [72] reported 4C2NP degradation via the formation of 4-chloro-2-aminophenol (4C2AP) by a co-culture of Enterobacter cloaceae and Alcaligenes sp. TK-2 [Figure 8]. A detoxification mechanism for 4C2NP transformation has been proposed for two Bacillus species [73,74]. In this mechanism, detoxification is initiated by the formation of 4C2AP, which acetylates into 4-chloro-2-acetaminophenol (4C2AAP). 4C2AAP is then converted to a non-toxic compound, 5-chloro-2-methylbenzoxazole [Figure 8]. Another investigation of complete mineralization of 4C2NP was published following the isolation of a 4C2NP-mineralization bacterium, Exiguobacterium sp. PMA [16]. This strain initiates 4C2NP degradation by the formation of $4 \mathrm{C} 2 \mathrm{AP}$ via a reduction mechanism, which is further dehalogenated into 2-aminophenol (2AP) through the release of chloride ions [16]. The further degradation of 2AP proceeds via ring cleavage and the removal of ammonium ions [Figure 8].

The metabolic pathway of 2C5NP has also been studied in C. necator JMP134, which utilizes 2C5NP as its sole carbon, nitrogen and energy source [75]. The first step of $2 \mathrm{C} 5 \mathrm{NP}$ degradation involves the reduction of 2C5NP to 2-chloro-5-hydroxylaminophenol (2C5HAP) by $3 \mathrm{NP}$-reductase [75]. In the second step, 2C5HAP undergoes Bamberger rearrangement to form 2-amino- 5-chlorohydroquinone (2A5CHQ) by mutase [Figure 9a]. In the next step, $2 \mathrm{~A} 5 \mathrm{CHQ}$ is reductively dehalogenated to 2-aminohydroquinone, which is further degraded by ring cleavage and ammonia release [75].

Pandey et al. [76] reported the biotransformation of 2C3NP to 3-nitrocatechol (3NC) in Burkholderia sp. SJ98. Initially, $2 \mathrm{C} 3 \mathrm{NP}$ is reductively dehalogenated to $3 \mathrm{NP}$, which is further hydroxylated to $3 \mathrm{NC}$ [Figure 9b].

\section{Bacterial degradation of CAPs and CMPs}

CAPs are amino derivatives of MCPs that are used in the manufacture of dyes. Examples include 4-chloro-2-aminophenol (4C2AP) and 2-chloro-4-aminophenol (2C4AP). Bacterial degradation of 4C2AP was studied in the Gram negative bacterium, Burkholderia sp. RKJ 800, which utilizes $4 \mathrm{C} 2 \mathrm{AP}$ as a sole carbon and energy source [17]. The degradation of $4 \mathrm{C} 2 \mathrm{AP}$ is initiated by the release of ammonium ion and the formation of $4 \mathrm{CC}$ by a deaminase. In the next step, 4CC is cleaved to cis, cis-chloromuconic acid by 4CC-1,2-dioxygenase (Figure 10a). Conversely, the bacterial degradation of 2C4AP was studied in a Gram positive bacterium, Arthrobacter sp. SPG, which utilized 2C4AP as its sole source of carbon and energy [18]. The first step of 2C4AP degradation involves removal of the ammonium ion by deaminase, which leads to formation of $\mathrm{CHQ}$ that is then dehalogenated to $\mathrm{HQ}$ by a CHQ-dehalogenase 


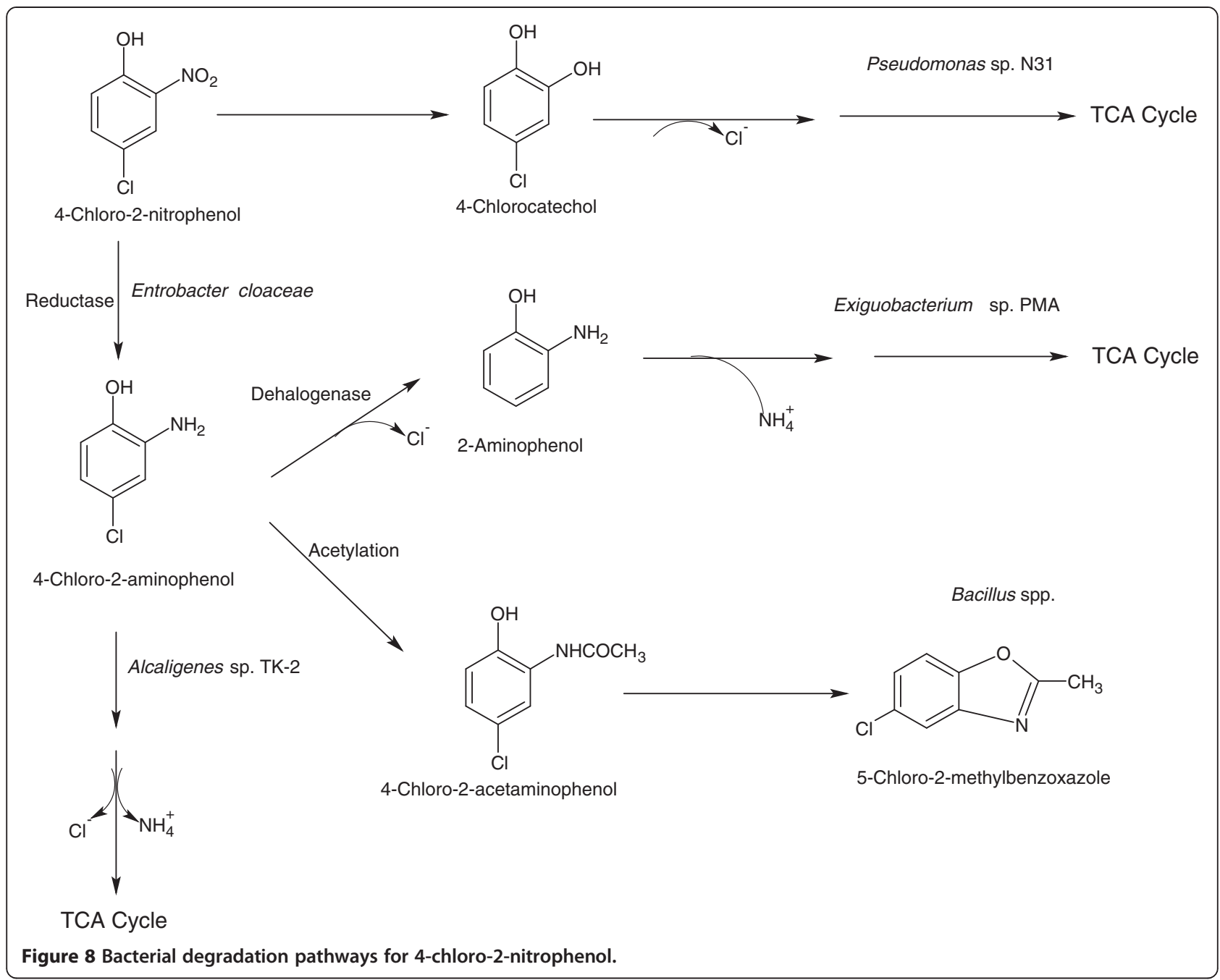

(Figure 10b). In the next step, HQ is cleaved to $\gamma$-hydroxymuconic semialdehyde by $\mathrm{HQ}$-1,2-dioxygenase $(\mathrm{EC}=$ 1.13.11.66) [18].

CMPs are methyl derivatives of CPs used for the manufacture of herbicides such as 4-chloro-3-methylphenol and 4-chloro-2-methylphenol. Lechner et al. [77] investigated the degradation pathway of $4 \mathrm{C} 2 \mathrm{MP}$ in a Gram negative strain, S-1. 4C2MP is first converted to 5-chloro-3-methylcatechol, which is ortho-cleaved into 4-chloro-2-methyl-cis-cis-muconate and then further degraded via the formation of 2-methyl-4-carboxymethylenebut-2-en-4-olide (Figure 10c).

\section{Anaerobic degradation of $\mathrm{CPs}$}

Anaerobic degradation of CPs is well studied in bacteria or various enrichment cultures derived from sediments collected from a variety of the sources [8]. Anaerobic degradation of various $\mathrm{CPs}$ proceeds via reductive dehalogenation in which chlorine atoms are replaced by hydrogen atoms [8]. In fact, the reductive dehalogenation is a crucial step for the anaerobic biodegradation of CPs especially for polyCPs. Several poly-CPs are recalcitrant towards aerobic bacterial attack and can be reductively dehalogenated into lesser chlorinated phenols that further mineralized easily. PCP may be reductively dehalogenated to 2,3,4,5-tetrachlorophenol (2,3,4,5-TeCP), then to 3,4,5-trichlorophenol (3,4,5-TCP), then to 3,5-dichlorophenol, then to 3CP and finally to phenol which further degraded to $\mathrm{CH}_{4}$ and $\mathrm{CO}_{2}$ by anaerobic bacteria [78,79] (Figure 11a). The combination of phenol-dehalogenating and phenol-degrading cultures was used for complete mineralization of PCP under anaerobic conditions [80]. In this process, a phenol-dehalogenating culture dehalogenates PCP to phenol under anaerobic conditions. The phenol is then further degraded by phenoldegrading culture under iron reducing or sulfate reducing conditions [80]. Becker et al. [81] studied two biotransformation pathways for $2 \mathrm{CP}$ in the anaerobic sediment slurry reactors. In the first pathway, $2 \mathrm{CP}$ is reductively dehalogenated to phenol, then carboxylated to 4hydroxybenzoate and finally dehydroxylated to benzoate 
(a)<smiles>O=[N+]([O-])c1ccc(Cl)c(O)c1</smiles>

Reductas
2-Chloro-5-hydroxylaminophenol<smiles>CC(C)CCCCCCCO</smiles><smiles>Nc1cc(O)c(Cl)cc1O</smiles>

2-Amino-5-chlorohydroquinone<smiles>CCOC(C)C</smiles>

$\mathrm{OH}$<smiles>Nc1cc(O)ccc1O</smiles>

2-Aminohydroquinone

(b)<smiles>O=[N+]([O-])c1cccc(O)c1Cl</smiles><smiles>Cl[C@H]1CCC[C@@H]1Cl</smiles>

2-Chloro-3-nitrophenol<smiles>O=[N+]([O-])c1cccc(O)c1</smiles>

3-Nitrophenol
Monooxygenase<smiles>O=[N+]([O-])c1cccc(O)c1O</smiles>

3-Nitrocatechol

Figure 9 Bacterial degradation pathway for 2-chloro-5-nitrophenol (a), and 2-chloro-3-nitrophenol (b).

(a)<smiles>Nc1cc(Cl)ccc1O</smiles>

4-Chloro-2-aminophenol

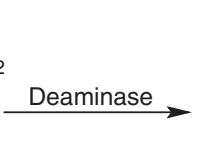

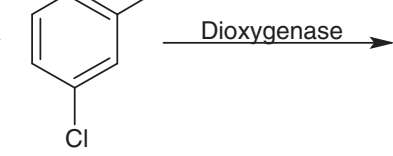

4-Chlorocatechol

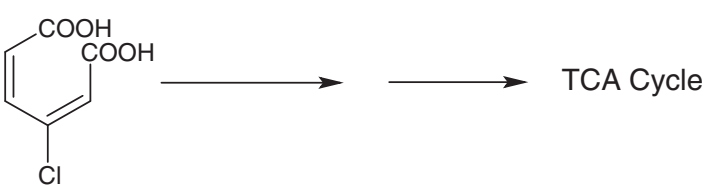

3-Chloro-cis-cis-muconic acid

(b)<smiles>Nc1ccc(O)c(Cl)c1</smiles>

2-Chloro-4-aminophenol

2-Chlorohydroquinone

Hydroquinone<smiles>CC(C)CCC=CC(=O)O</smiles>

$\gamma$-Hydroxymuconicsemialdehyde (c)<smiles>CO[C@H](O)[C@H](O)c1cc(Cl)cc(Cl)c1O</smiles>

3-Methyl-4-nitrophenol<smiles>Cc1cc(Cl)cc(C=CC(=O)O)c1</smiles>

4-Chloro-2-methyl- cis-cis-muconate

2-Methyl-4-carboxymethylenebut-2-en-4-olide

Figure 10 Bacterial degradation pathways for 4-chloro-2-aminophenol (a), 2-chloro-4-aminophenol (b), and 4-chloro-2-methylphenol (c). 


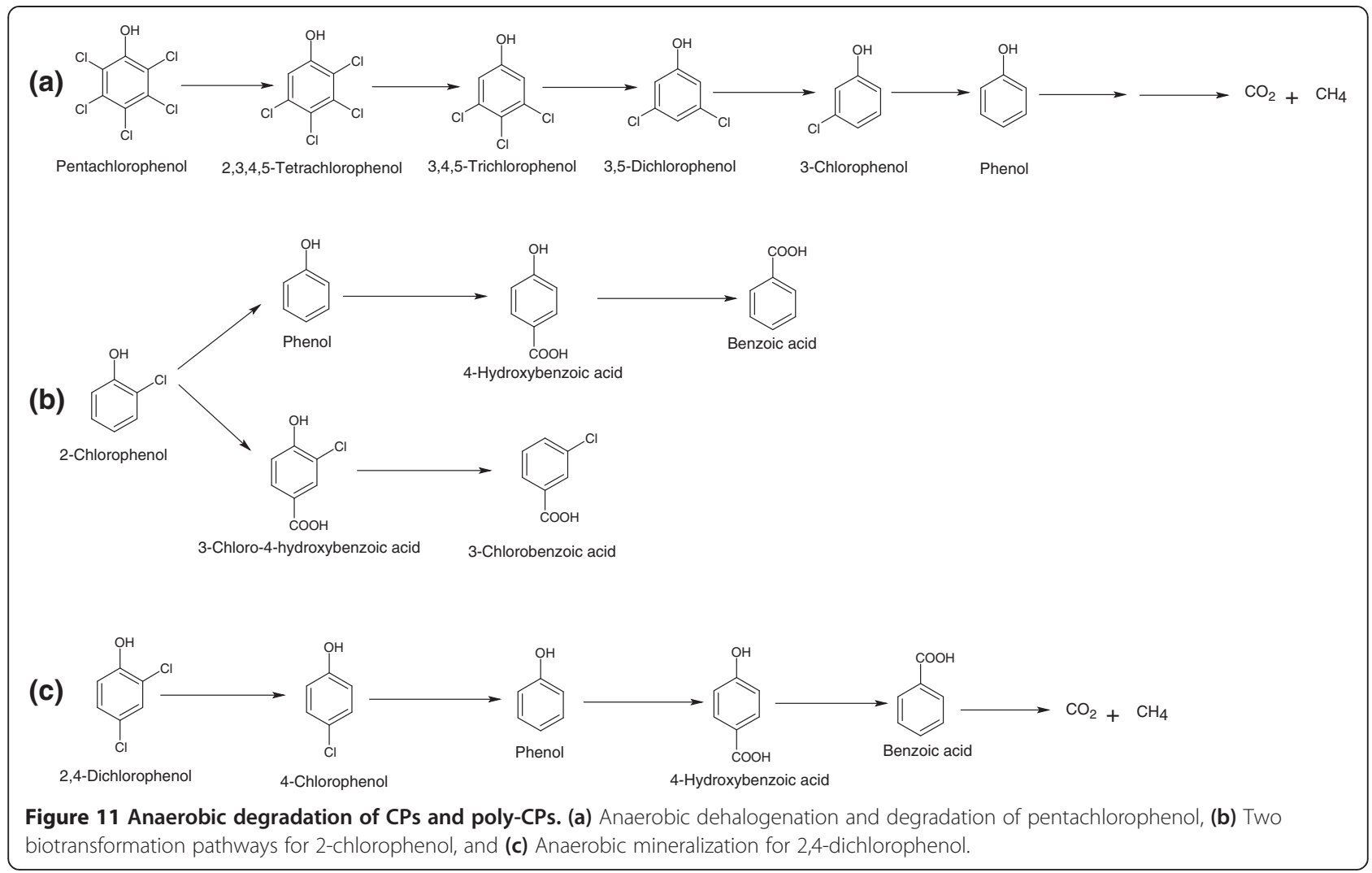

(Figure 11b). In the second pathway, $2 \mathrm{CP}$ is para-carboxylated to 3-chloro-4-hydroxybenzoate, which is further dehydroxylated to 3-chlorobenzoate.The mineralization of ${ }^{14} \mathrm{C}$-radiolabeled $4 \mathrm{CP}, 2 \mathrm{CP}$, and 2,4-DCP to ${ }^{14} \mathrm{CH}_{4}$ and ${ }^{14} \mathrm{CO}_{2}$ was studied in acclimated sludge [82]. In this process, 4CP is mineralized via phenol, 4hydroxybenzoate and benzoate, while 2,4-DCP is mineralized via 4CP, phenol, 4-hydroxybenzoate and benzoate [82] (Figure 11c).

Methanogenic, sulfate reducing, iron-reducing and denitrifying conditions favor anaerobic degradation and reductive dechlorination of CPs. Anaerobic degradation and dechlorination of CPs have been extensively studied under methanogenic conditions [78,83-87]. A PCP acclimated methanogenic consortium reductively dechlorinated PCP and TeCPs [83]. In this process, PCP is first dechlorinated to 2,3,4,5-TeCP, 2,3,4,6-tetrachlorophenol and 2,3,5,6-tetrachlorophenol. These TeCPs are then further dehalogenated to TCPs, DCPs and MCPs. Another methanogenic enrichment culture derived from sewage sludge transformed 2,4,6-TCP, 2,4,5-TCP and 3,4,5-TCP [84]. In this process, $2,4,6$-TCP is reductively dechlorinated to $4 \mathrm{CP}$ via $2,4-\mathrm{DCP}$, whereas $2,4,5-\mathrm{TCP}$ and $3,4,5-$ TCP are dehalogenated to 3 CP via 3,4-DCP [84]. The reductive dechlorination of 12 isomers of CPs and poly-CPs including MCPs, DCPs, TCPs, TeCPs and PCP was also investigated using methanogenic cultures [85]. Takeuchi et al.
[86] reported dehalogenation and transformation of 19 isomers of $\mathrm{CPs}$ under methanogenic conditions. A fresh water sediment mineralized 2,4-DCP into $\mathrm{CO}_{2}$ and methane via $4 \mathrm{CP}$, phenol and benzoate [87].

The mineralization of CPs has been found to be coupled with sulfate reduction. Haggblom and Young [88] developed a CPs-mineralizing sulfate reducing consortia from estuarine sediment that was maintained on 2CP, $3 \mathrm{CP}$ or $4 \mathrm{CP}$ as the only source of carbon and energy for several years [89]. Their experiments utilizing a 4CP-utilizing consortium revealed that mineralization of $4 \mathrm{CP}$ into $\mathrm{CO}_{2}$ was coupled to sulfate reduction, and that $4 \mathrm{CP}$ depletion did not occur in the absence of sulfate. In this reaction, sulfate, thiosulfate or sulfite were used as electron acceptors [89]. The coupling of sulfate reduction with mineralization of CPs was also observed in degradation of $2 \mathrm{CP}$ or $4 \mathrm{CP}$ by sulfate reducing enrichment cultures derived from Hudson River sediment [90].

Under denitrifying conditions, the 2CP degradation was studied in enrichment cultures derived from activated sludge samples [91]. The presence of nitrate was essential as electron acceptors for the mineralization of $2 \mathrm{CP}$ into $\mathrm{CO}_{2}$ [91]. Sanford and Tiedje [92] studied dechlorination and subsequent degradation of MCPs and DCPs in anaerobic microcosms supplemented with $1 \mathrm{mM}$ or $5 \mathrm{mM}$ nitrate. 
CPs degradation is associated with reduction of $\mathrm{Fe}^{3+}$ to $\mathrm{Fe}^{2+}$. An anaerobic enrichment culture derived from Hudson River sediments mineralized 2CP, 3CP and 4CP with concomitant reduction of $\mathrm{Fe}^{3+}$ to $\mathrm{Fe}^{2+}$ [93]. Several factors may affect dechlorination of CPs and reduction of Fe. For example, a low amount of nitrate enhances reductive dechlorination of PCP and Fe(III) reduction, while high concentrations of nitrate inhibit reductive dechlorination and Fe(III) reduction [94].

The reductive dehalogenation of MCPs and DCPs was investigated in the anaerobic sediment samples of estuarine Lake Shinji and Lake Nakaum [95]. Estuarine sediment enrichment cultures of lake Shinji dehalogenated $2 \mathrm{CP}, 3 \mathrm{CP}$ and 2,6-DCP, whereas enrichment cultures of Lake Nakaum dehalogenated 3CP and 2,6-DCP [95]. The dehalogenated product of MCPs was phenol, which was further degraded by the formation of benzoic acid. Itoh et al. [96] identified the bacterial consortia involved in dehalogenation of MCP into phenol and transformation of phenol to benzoic acid using polymerase chain reaction-denaturing gradient gel electrophoresis (PCRDGGE) of the $16 \mathrm{~S}$ rRNA gene in the enrichment sample of Lake Shinji. The 4CP-dechlorinating culture had two dominant bacteria, in which one belonged to Dehalobacter sp. In the phenol transforming culture, Cryptanaerobacter phenolicass was present.

Li et al. [97] established a simple anaerobic upflow column system (15 cm long, $5 \mathrm{~cm}$ inner diameter) for complete PCP-mineralization using a microbial consortium requiring only lactate as an external nutrient. Anaerobic microbes dehalogenated PCP to $3 \mathrm{CP}$ and phenol using external lactate as an electron donor [97]. The further degradation of $3 \mathrm{CP}$ and phenol proceeded without an external electron donor and the nitrogen required for degradation was supplied by nitrogen-fixation [97]. The potential dechlorinators, Dehalobacter and Desulfitobacterium, and the phenol/3CP fermentative or syntrophic degraders, Cryptanaerobacter and Syntrophus, were found at the bottom of the column, whereas the nitrogen-fixing facultative anaerobe, Rhizobiales, was detected in the top of the upflow column, and other possible nitrogen-fixers were found at both the bottom and top of the upflow column [97].

A variety of pure bacterial cultures have been characterized for their ability to dechlorinate CPs under anaerobic conditions [98-101]. For example, several species of Desulfitobacterium with dehalogenating capabilities toward various CPs have been isolated and characterized, including Desulfitobacterium hafniense PCP-1 [98], D. hafniense DCB-2 [99], D. dehalogenans IW/IU-DC1 [102] and D. chlororespirans [103]. These strains utilize CPs as electron acceptors for growth during the oxidation of electron donating chemicals in a process known as halorespiration [8]. Villemur [98] reported that $D$. hafniense PCP-1 isolated from a methanogenic consortium was able to dehalogenate PCP to $3 \mathrm{CP}$ via the formation of 3,4,5-TCP and 3,5-DCP. Strain PCP-1 was also capable of dehalogenation of other TCPs and DCPs, but unable to dehalogenate MCPs [98]. D. hafniense strain DCB-2 removed the ortho-substituted chorine from 2,4,6-TCP, 2,4,5-TCP, PCP, 2,4-DCP, and metasubstituted chlorine from 3,5-DCP [98]. Apart from Desulfitobacterium spp., other dehalorespirating bacteria include Desulfomonile tiedje DCB-1 [100] and Anaeromyxobacter dehalogenans [101]. Mohn and Kennedy [100] reported the dehalogenation of PCP into 2,4,6TCP by 3-chlorobenzoate-induced cells of a sulfate reducing bacterium, Desulfomonile tiedje DCB-1. He and Sandford [104] reported ortho-dehalogenation of 2,6-DCP and 2CP to phenol by a facultative anaerobic bacterium, Anaeromyxobacter dehalogenans 2CP-C. Recently, Wang et al. [105] reported the removal of the ortho-chlorines from 2,4,6-TCP by Dehalobacter sp. PCP-1 that converted 2,4,6-TCP to 4CP via 2,4-DCP.

\section{Genetics of bacterial degradation of CPs}

The genes responsible for degradation of CPs are located on either plasmids or chromosomal DNA. Plasmid encoded genes include (i) two $t d f$ operons on the C. nector JMP134 plasmid pJP4 [106], (ii) tcpRXABCYD cluster on C. necator JMP134 (pJP4) [107], (ii) the clc operon on the Pseudomonas knackmussii plasmid pB13 (pWR1) [108], and (iv) the $t c b$ operon on the Pseudomonas sp. P51 plasmid pP51 [109]. Two $t d f$ gene clusters $\left(t f d C_{I} D_{I} E_{I} F_{I}\right.$ and $\left.t f d D_{I I} C_{I I} E_{I I} F_{I I}\right)$ identified on plasmid pJP4 of strain JMP134 encode enzymes for $4 \mathrm{CC}$ metabolism. The genes $t f d \mathrm{C}, t f d \mathrm{D}, t f d \mathrm{E}$ and $t f d \mathrm{~F}$ encode the enzymes chlorocatechol-1,2-dioxygenase (EC 1.13.11.-) (TfdC), chloromuconate cycloisomerase $(\mathrm{TfdD}) \quad(\mathrm{EC}=5.5 .1 .7)$, dienelactone hydrolase $(\mathrm{TfdE})$ $(\mathrm{EC}=3.1 .1 .45)$, and maleylacetate reductase $(\mathrm{TfdF})(\mathrm{EC}=$ 1.3.1.32), respectively [106]. Van der Meer et al. [109] reported that genes $t c b \mathrm{C}, t c b \mathrm{D}$ and $t c b \mathrm{E}$ located on the operon $t c b$ (pP51) encoded a catechol 1,2-dioxygenase II (EC 1.13.11.1), a cycloisomerase II $(\mathrm{EC}=5.5 .1 .7)$, and a hydrolase II $(\mathrm{EC}=3.1 .1 .45)$, respectively which degraded 3,4-dichlorocatechol and 3,4,6-trichlorocatechol to chloromaleylacetate. The clc operon contains the genes for utilization of CCs on the Pseudomonas sp. P51 plasmid pP51 [108]. These genes include $\operatorname{cic} A$, the gene encoding catechol oxygenase II (EC 1.13.11.1), $c l c \mathrm{~B}$, the gene encoding muconate cycloisomerase II $(\mathrm{EC}=5.5 .1 .7)$, and $c l c D$, the gene encoding dienelactone hydrolase $(\mathrm{EC}=$ 3.1.1.45). The genes for degradation of 2,4,6-TCP are located on the tcpRXABCYD cluster from $C$. necator JMP134 (pJP4) [107]. The gene tcpA encodes a reduced flavin adenine dinucleotide (FADH2)-dependent monooxygenase $(\mathrm{TcpA})(\mathrm{EC}=1.14 .13-)$ that converts $2,4,6-\mathrm{TCP}$ to 6-chlorohydroxyquinol. TcpA needs FADH2 that is 
supplied by the putative flavin reductase (TcpX) encoded by the $t c p X$ gene [107]. The $t c p B$ gene may also encode flavin reductase activity because it showed sequence similarity to genes coding for nitroreductases [107]. The gene $t c p C$ encodes an enzyme 6-chlorohydroxyquinol-1,2-dioxygenase $(\mathrm{TcpC})(\mathrm{EC}=1.13 .11$.- $)$ that cleaves chlorohydoxyquinol to 2-chloromaleylacetate. The gene $t c p \mathrm{D}$ encodes an enzyme maleylacetate reductase $(\mathrm{TcpD})(\mathrm{EC}=1.3 .1 .32)$ that converts chloromaleylacetate to $\beta$-ketoadipate. The gene $t c p R$ is a regulator that controls the expression of all $t c p$ genes whereas the function of $t c p \mathrm{Y}$ is not clear [107]. In Ralstonia picketti DTP0602, two gene clusters (had$X A B C$ and hadYD) are involved in the conversion of 2,4,6-TCP to 3-oxoadipate, where hadXABC and hadYD are regulated by $h a d R$ and hadS, respectively [110]. Torii et al. [111] investigated how HadR regulates 2,4,6-TCP catabolic pathway gene expression in Ralstonia pickettii DTP0602. They found that purified HadR binds to the hadX promoter and HadR-DNA complex formation is induced in the presence of 16 types of substituted phenols, including CPs, nitrophenols and tribromophenols.

A gene cluster containing four genes (clcA2, clcB2, clcD2 and $c l c F$ ) involved in a new modified ortho-cleavage pathway of 3CC was identified in Rhodococcus opacus 1CP [47]. The genes $c l c \mathrm{~A} 2, c l c \mathrm{~B} 2, c l c \mathrm{D} 2$ and $c l c \mathrm{~F}$ encode the enzymes 3-chlorocatechol-1,2-dioxygenase (ClcA2), chloromuconate cycloisomerase $(\mathrm{ClcB} 2)$, dienelactone hydrolase $(\mathrm{ClcD} 2)$ and muconolactone isomerase-related enzyme (ClcF), respectively. This organism also contains a second cluster of chlorocatechol degradation genes that are similar to the proteobacterial genes [41].

A 4CP-degradation gene cluster (cph genes) was identified in A. chlorophenolicus [12]. This gene cluster contains 10 open reading frames that show similarity to the genes encoding the enzymes involved in CP degradation. Several open reading frames encode enzymes with similar functions. For example, two genes, cphA-1 and cph-11, encode functional hydroxyquinol-1,2-dioxygenase. A mutant strain constructed by disturbing the gene $c p h A-1$ by site-directed mutagenesis was unable to utilize 4CP as the sole source of carbon energy. Other genes present on this cluster include $c p h \mathrm{C}$-I, $c p h C$-II, $c p h F$-I, $c p h F$-II, $C p h$ B, CphX, CphR and CphS. The genes $c p h C$-I and $c p h C$-II encode putative monooxygenase, whereas $c p h \mathrm{~F}-1$ and $c p h \mathrm{~F}-11$ encode putative maleylacetate reductase and $c p h \mathrm{~B}$ encodes a NADH:flavin adenine dinucleotide oxidoreductase. The roles of the remaining genes in the $c p h$ gene cluster have yet to be determined [112].

The ccaBARCD gene cluster is involved in CC degradation in Pseudomonas reinekei MT1 [112]. The genes $c c a A, c c a B, c c a C$ and $c c a D$ encode the enzymes catechol-1,2-dioxygenase, (chloro) muconate cycloisomerase, trans-dienelactone hydrolase and maleylacetate reductase, respectively. The gene, ccaR is a putative regulator homologous to regulators of the IclR-type family [112].

Genes for degradation of 2,4,5-TCP have been identified and characterized from Burkholderia phenoliruptrix AC1100 [61,62,113-115]. Two gene clusters, $t f t C D$, and tftEFGH, are involved in conversion of 2,4,5-TCP to 3oxoadipate in B. phenoliruptrix AC1100 [61,62,113-115].

Several genes $(p c p B, p c p C, p c p A$ and $p c p E)$ involved in PCP degradation have been identified and characterized from Sphingomonas chlorophenolicum L-1 [116]. The genes $p c p B, p c p C, p c p A$ and $p c p E$ encode the enzymes PCP-4monooxygenase $(\mathrm{PcpB})(\mathrm{EC}=1.14 .13 .50), \mathrm{TeCH}$-reductive dehalogenase (PcpC) (EC = 1.8.99-), DiCHQ-1,2-dioxygenase (PcpA) (1.13.11.-), maleylacetate reductase $(\mathrm{EC}=$ 1.3.1.32), respectively. PcpB is a flavin monooxygenase that converts $\mathrm{PCP}$ to $\mathrm{TeCHQ}$ via hydroxylation at the para-position with removal of the chloride ion in the first step of the bacterial degradation of PCP. РсрB has broad substrate specificity and catalyzes reaction of various substituted aromatic compounds [117]. The $p c p \mathrm{~B}$ gene has also been detected in three other strains of Sphingonium chlorophenolicum (RP-2, SR-3 and ATCC 33790). An identical $p c p$ B gene sequence was found in three strains (L-1, RP-2, SR-3) $[118,119]$, whereas the $p c p \mathrm{~B}$ gene sequence of Sphinogomonads strain UG-30 showed 90\% sequence similarity with that of Sphingonium chlorophenolicum ATCC 39723 [120-122]. Homologues of the $p c p \mathrm{~B}$ gene have also been detected in the polychlorinated degrading bacterium, Novosphingonium sp. strain MT1 [123], and in two non-PCP degrading $\beta$ - and $\gamma$ - proteobacterial strains [124]. In the second step of the PCP degradation, PcpC catalyzes the reductive dehalogenation of TeCHQ to 2,6-DCHQ, which is further cleaved to 2-chloromaleylacetate by PcpA. PcpE converts 2-chloromaleylacetate to 3-oxoadipate via maleylacetate. Another gene, $p c p \mathrm{R}$ is a LysR-type regulator that is essential to the induction of $p c p B, p c p A$, and $p c p E$.

\section{Genetics of reductive dehalogenation}

Reductive dehalogenation of CPs and poly-CPs is generally carried out by chlorophenol reductive dehalogenases (CprA) encoded by the cprA gene, which have been well-studied in Desulfitobacterium hafniense PCP-1, D. dehalognase IW/IU-DC1, and D. chlororespirans [98]. The cprA genes are associated with $c p r$ gene clusters that also encode several accessory proteins (e.g., CprAanchor protein [98,125], chaperones, regulators [126]). The cpr gene clusters composed of eight genes (cprT, cprK, cprZ, cprE, cprB, cprA, cprC, and $c p r D$ ) have been identified in the genome of Desulfitobacterium dehalogenans IW/IU-DC1 and Desulfitobacterium hafniense DCB-2 [126,127]. CprK, a member of the CRP-FNR (cAMP-binding protein/fumarate nitrate reduction regulatory protein) family regulators, control transcription of the cpr genes [128]. The mechanism responsible for 
regulation of transcription of $c p r$ genes has been investigated [128]. An effector domain of CprK interacts with a chlorinated aromatic compound with high affinity which induces its binding to an upstream target DNA sequence known as the "dehalobox to activate the transcriptions of the cpr genes [128].

Four genes (cprA2, cprA3, cprA4 and cprA5) encoding the putative chloroaromatic reductive dehalogenases (CprA2-A5) have been identified in D. hafniense PCP-1 [129-132]. Two gene products (CprA3 and CprA5) have been purified and characterized. CprA3 catalyzes orthodechlorination of highly chlorinated phenols including PCP, 2,3,4,5-TeCP, 2,3,4-TCP, 2,4,6-TCP and 2,3,6-TCP, whereas CprA5 catalyzes meta-dechlorination of 3,5-DCP and 2,3,5-TCP, para-dechlorination of PCP, 2,3,4,5-TeCP and 3,4,5-TCP, and ortho-dechlorination of 2,4,6-TCP, 2,4,5-TCP and 2,4-DCP [131,132]. The dehalogenation activities of the products of another two genes (cprA2 and cprA3) are not yet known. The transcription levels of the cprA2, cprA3, cprA4 and cprA5 genes were measured in strain PCP cultures exposed to CPs by reverse transcription-quantitative PCR [133]. The genes cprA2 and cprA3 were upregulated in cultures amended with 2,4,6-TCP, whereas only cprA5 was upregulated in 3,5DCP-amended cultures. In PCP-amended cultures grown for $12 \mathrm{~h}, c p r A 2$ and cprA3 were upregulated, but cprA5 was not. The gene, cprA4 was not upregulated significantly in cultures containing any tested CPs [133].

A non-CprA reductive dehalogenase known as CrdA from $D$. hafniense strain $\mathrm{PCP}-1$ cultures amended with 2,4,6 TCP has been isolated and characterized. CrdA catalyzes ortho-dehalogenation of PCP and 2,4,6-TCP [134]. The gene $(\operatorname{crd} \mathrm{A})$ encoding $\mathrm{CrdA}$ has been cloned and sequenced from strain PCP-1 and also detected in several other strains of Desulfitobacterium [134]. Gauthier et al. [129] monitored the expression of the crd gene in Desulfitobacterium strains and transcripts of $c r d \mathrm{~A}$ were detected in D. hafniense strains PCP-1, DCB-2 and TCE-1.

\section{Conclusions}

The bacterial degradation of MCPs and poly-CPs has been extensively studied and several pathways have been proposed for degradation of MCPs and poly-CPs. The bacterial degradation of CPs and poly-CPs proceeded via formation of the corresponding CCs or the corresponding (chloro)HQs. The genes involved in the degradation of MCPs and poly-CPs have also been identified and characterized from CPs-degrading bacteria.

CAPs and CMPs are highly toxic compounds, and few studies have been conducted to investigate the biodegradation of these compounds. More CAPs and CMPsdegrading bacteria must be isolated to investigate the genetic and biochemical mechanism by which these compounds are degraded.
Anaerobic degradation of CPs has also been studied, and it has been established that MCPs and poly-CPs are initially dehalogenated to phenol, which is further transformed to benzoic acid and then mineralized to $\mathrm{CO}_{2}$ under anaerobic conditions. However, further study is needed to elucidate the genetic and enzymatic basis of this mechanism. Furthermore, anaerobic degradation of other CPs such as CNPs, CAPs and CMPs should also be studied.

\section{Abbreviations}

CPs: Chlorophenols; MCPs: Monochlorophenols; poly-CPs: Polychlorophenols; CNPs: Chloronitrophenols; CAPs: Chloroaminophenols;

CMPs: Chloromethylphenols; 2CP: 2-Chlorophenol; 3CP: 3-Chlorophenol; 4CP: 4-Chlorophenol; CC: Chlorocatechol; 4CC: 4-Chlorocatechol; 3CC: 3-Chlorocatchol; 2CC: 2-Chlorocatechol; HQ: Hydroquinone; 5C2HMS: 5-Chloro-2-hydroxymuconic semialdehyde; BT: 1,2,4-Benzenetriol; 4CC-BT pathway: 4-Chlorocatechol-benzenetriol pathway;

CMCl: Chloromuconate cycloisomerase; CMLI: Chloromuconolactone isomerase; DELH: Dienelactone hydrolase; DCPs: Dichlorophenols;

TCPs: Trichlorophenols; TeCPs: Tetrachlorophenols; PCP: Pentachlorophenol; 2,4-DCP: 2,4-Dichlorophenol; 2,4,6-TCP: 2,4,6-Trichlorophenol;

2,4,5-TCP: 2,4,5-Trichlorophenol; 2,4-D: 2,4-Dichlorophenoxyacetic acid; DiCBQ: 2,5-Dichloro-p-benzoquinone; 2,5-DiCHQ: 2,5-Dichlorohydroquinone; CHHQ: 5-Chloro-2-hydroxy-p-hydroquinone; TeCHQ: Tetrachlorohydroquinone; 2,6-DCHQ: 2,6-Dichloro-1,4-hydroquinone; 2C4NP: 2-Chloro-4-nitropheol; 4C2NP: 4-Chloro-2-nitrophnol; 4C3NP: 4-Chloro-3-nitrophenol;

2C5NP: 2-Chloro-5-nitrophenol; 2C3NP: 2-Chloro-3-nitrophenol; 4NP: 4-Nitrophenol; CHQ: Chlorohydroquinone;

4C2AP: 4-Chloro-2-aminophenol; 4C2AAP: 4-Chloro-2-acetaminophenol; 2AP: 2-Aminophenol; 2C5HAP: 2-Chloro-5-hydroxylaminophenol;

2A5CHQ: 2-Amino-5-chlorohydroquinone; 3NC: 3-Nitrocatechol; 4C2AP: 4-Chloro-2-aminophenol; 2C4AP: 2-Chloro-4-aminophenol; 2,3,4,5-TeCP: 2,3,4,5-Tetrachlorophenol; 3,4,5-TCP: 3,4,5-Trichlorophenol; TCA Cycle: Tricarboxylic acid cycle.

\section{Competing interests}

The authors declare that they have no competing interests.

\section{Authors' contributions}

PKA collected all the relevant publications, arranged the general structure of the review, drafted the text and produced figures. HHB revised and

formatted the review and also help to draft the manuscript. All authors read and approved the final manuscript.

\section{Acknowledgement}

This research was supported by a Yeungnam University Research Grant (213A345032)

Received: 15 January 2014 Accepted: 20 February 2014

Published: 3 March 2014

\section{References}

1. National Pollutant Inventory: Department of the environment, water, heritage and the arts, Australia. [http://www.npi.gov.au/resource/ chlorophenols-di-tri-tetra]

2. Muller F, Caillard L: Chlorophenols. In Ullmann's Encyclopedia of Industrial Chemistry. John Wiley \& Sons, Inc; 2011. DOI: 10.1002/14356007.a07_001. pub2.

3. Olaniran $\mathrm{AO}$, Igbinosa $\mathrm{EO}$ : Chlorophenols and other related derivatives of environmental concern: properties, distribution and microbial degradation processes. Chemosphere 2011, 83:1297-1306.

4. Agency for Toxic Substances and Disease Registry (ATSDR): Toxicological Profile for Chlorophenols. Atlanta, GA: U.S Department of Health and Human Services, Public Health Service; 1999

5. Igbinosa EO, Odjadjare EE, Chigor VN, Igbinosa $\mathrm{H}$, Emoghene AO, Ekhaise FO, Igiehon NO, Idemudia OG: Toxicological profile of chlorophenols and their derivatives in the environment: the public health perspective. Sci World J 2013, 2013:11. doi:10.1155/2013/460215. 
6. Pera-Titus M, García-Molina V, Baños MA, Giménez J, Esplugas S: Degradation of chlorophenols by means of advanced oxidation processes: a general review. App/ Catal B Environ 2004, 47(4):219-256.

7. Solyanikova IP, Golovleva LA: Bacterial degradation of chlorophenols: pathways, biochemica, and genetic aspects. J Environ Sci Health B 2004 39(3):333-351.

8. Field JA, Sierra-Alvarez R: Microbial degradation of chlorinated phenols. Rev Environ Sci Biotechnol 2008, 7:211-241.

9. Solyanikova I, Golovleva L: Biochemical features of the degradation of pollutants by Rhodococcus as a basis for contaminated wastewater and soil cleanup. Mikrobiologiia 2011, 80(5):579-594.

10. Hollender J, Hopp J, Dott W: Degradation of 4-Chlorophenol via the meta Cleavage Pathway by Comamonas testosteroni JH5. Appl Environ Microbiol 1997, 63(11):4567-4572.

11. Mars AE, Kasberg T, Kaschabek SR, van Agteren MH, Janssen DB, Reineke W: Microbial degradation of chloroaromatics: use of the meta-cleavage pathway for mineralization of chlorobenzene. J Bacteriol 1997 179:4530-4537.

12. Nordin K, Unell M, Jansson JK: Novel 4-chlorophenol degradation gene clusterand degradation route via hydroxyquinol in Arthrobacter chlorophenolicus A6. Appl Environ Microbiol 2005, 71(11):6538-6544.

13. Xun L, Topp E, Orser CS: Purification and characterization of a tetrachlorop-hydroquinone reductive dehalogenase from a Flavobacterium sp. J Bacteriol 1992, 174:8003-8007.

14. Arora PK, Jain RK: Metabolism of 2-chloro-4-nitrophenol in a gram negative bacterium, Burkholderia sp. RKJ 800. PLOS One 2012, 7(6):e38676.

15. Pandey J, Heipieper HJ, Chauhan A, Arora PK, Prakash D, Takeo M, Jain RK: Reductive dehalogenation mediated initiation of aerobic degradation of 2-chloro-4-nitrophenol (2C4NP) by Burkholderia sp. strain SJ98. Appl Microbiol Biotechnol 2011, 92:597-607.

16. Arora PK, Sharma A, Mehta R, Shenoy BD, Srivastava A, Singh VP. Metabolism of 4-chloro-2-nitrophenol in a gram-positive bacterium, Exiguobacterium sp. PMA. Microb Cell Fact 2012, 11:150.

17. Arora PK, Srivastava A, Singh VP: Novel degradation pathway of 4-chloro2-aminophenol via 4-chlorocatechol in Burkholderia sp. RKJ 800. Environ Sci Pollut Res Int 2013. Doi: 10.1007/s11356-013-2167-y.

18. Arora PK, Srivastava A, Singh V: Novel degradation pathway of 2-chloro-4aminophenol in Arthrobacter sp. SPG. PeerJ PrePrints 2014, 2:e194v1. http:// dx.doi.org/10.7287/peerj.preprints.194v1.

19. Nikodem $P$, Hecht $V$, Schlömann M, Pieper DH: New bacterial pathway for 4- and 5-chlorosalicylate degradation via 4-chlorocatechol and maleylacetate in Pseudomonas sp. strain MT1. J Bacterio/ 2003, 185(23):6790-6800.

20. Dorn E, Hellwig M, Reineke W, Knackmuss HJ: Isolation and characterization of a 3-chlorobenzoate degrading pseudomonad. Arch Microbiol 1974, 99(1):61-70.

21. Weisshaar MP, Franklin FC, Reineke W: Molecular cloning and expression of the 3-chlorobenzoate-degrading genes from Pseudomonas sp. strain B13. J Bacteriol 1987, 169(1):394-402.

22. Ajithkumar PV, Kunhi AA: Pathways for 3-chloro- and 4-chlorobenzoate degradation in Pseudomonas aeruginosa 3mT. Biodegradation 2000, 11(4):247-261.

23. Arensdorf JJ, Focht DD: Formation of chlorocatechol meta cleavage products by a pseudomonad during metabolism of monochlorobiphenyls. Appl Environ Microbio/ 1994, 60(8):2884-2889.

24. Stolz A, Busse HJ, Kämpfer P: Pseudomonas knackmussii sp. nov. Int J Syst Evol Microbiol 2007, 57(Pt 3):572-576.

25. Knackmuss HJ, Hellwig M: Utilization and cooxidation of chlorinated phenols by Pseudomonas sp B-13. Arch Microbiol 1978, 117:1-7.

26. Fava F, Armenante PM, Kafkewitz D: Aerobic degradation and dechlorination of 2-chlorophenol, 3-chlorophenol and 4-chlorophenol by a Pseudomonas pickettii strain. Lett Appl Microbiol 1995, 21(5):307-312

27. Finkel'shtein ZI, Baskunov BP, Golovlev EL, Moiseeva OV, Vervoort J, Rietjens I, Golovleva LA: Dependence of the conversion of chlorophenols by rhodococci on the number and position of chlorine atoms in the aromatic ring. Microbiology 2000, 69:40-47.

28. Menke B, Rehm HJ: Degradation of mixtures of monochlorophenols and phenol as substrates for free and immobilized cells of Alcaligenes sp. A7-2. Appl Microbiol Biotechnol 1992, 37:655-661.

29. Hollender J, Hopp J, Dott W: Cooxidation of chloro- and methylphenols by Alcaligenes xylosoxidans JH1. World J Microbiol Biotechnol 2000, $16: 445-450$
30. Bae HS, Rhee SK, Cho YG, Hong JK, Lee ST: Two different pathways (a chlorocatechol and a hydroquinone pathway) for the 4-chlorophenol degradation in two isolated bacterial strains. J Microbiol Biotechnol 1997, 7:237-241.

31. Westerberg K, Elvang AM, Stackebrandt E, Jansson JK: Arthrobacter chlorophenolicus sp nov., a new species capable of degrading high concentrations of 4-chlorophenol. Int J Syst Evol Microbiol 2000, 50:2083-2092.

32. Bae HS, Lee JM, Kim YB, Lee ST: Biodegradation of the mixtures of 4-chlorophenol and phenol by Comamonas testosteroni CPW301. Biodegradation 1997, 7:463-469.

33. Im WT, Bae HS, Yokota A, Lee ST: Herbaspirillum chlorophenolicum sp. nov., a 4-chlorophenol-degrading bacterium. Int J Syst Evol Microbiol 2004, 54(Pt3):851-855.

34. Konovalova El, Solyanikova IP, Golovleva LA: Degradation of 4-chlorophenol by the bacterium Rhodococcus opacus 6a. Microbiol (Moscow, Engl Transl) 2009, 78(6):805-807.

35. Bae HS, Lee JM, Lee ST: Biodegradation of 4-chlorophenol via a hydroquinone pathway by Arthrobacter ureafaciens CPR706. FEMS Microbiol Lett 1996, 145(1):125-129.

36. Solyanikova IP, Golovleva LA: Biochemical Features of the degradation of pollutants by Rhodococcus as a basis for contaminated wastewater and soil cleanup. Microbiology 2011, 80(5):591-607.

37. Cho YG, Yoon JH, Park YH, Lee ST: Simultaneous degradation of pnitrophenol and phenol by a newly isolated Nocardioides sp. J Gen Appl Microbiol 1998, 44:303-309.

38. Golovleva LA, Zaborina O, Pertsova R, Baskunov B, Schurukhin Y, Kuzmin S: Degradation of polychlorinated phenols by Streptomyces rochei 303. Biodegradation 1992, 2:201-208.

39. Farrell A, Quilty B: Degradation of mono-chlorophenols by a mixed microbial community via a meta- cleavage pathway. Biodegradation 1999, 10(5):353-362.

40. Moiseeva OV, Belova OV, Solyanikova IP, Schlömann M, Golovleva LA: Enzymes of a new modified ortho-pathway utilizing 2-chlorophenol in Rhodococcus opacus 1CP. Biochemistry (Mosc) 2001, 66(5):548-555.

41. Moiseeva OV, Solyanikova IP, Kaschabek SR, Gröning J, Thiel M, Golovleva LA, Schlömann MA: New modified ortho cleavage pathway of 3-chlorocatechol degradation by Rhodococcus opacus 1CP: genetic and biochemical evidence. J Bacteriol 2002, 184(19):5282-5292.

42. Bartels I, Knackmuss HJ, Reineke W: Suicide inactivation of catechol 2,3-dioxygenase from Pseudomonas putida $\mathrm{mt}-2$ by 3-halocatechols. Appl Environ Microbiol 1984, 47(3):500-505.

43. Kunze M, Zerlin KF, Retzlaff A, Pohl JO, Schmidt E, Janssen DB, Vilchez-Vargas R, Pieper DH, Reineke W: Degradation of chloroaromatics by Pseudomonas putida GJ31: assembled route for chlorobenzene degradation encoded by clusters on plasmid pKW1 and the chromosome. Microbiology 2009, 155(Pt12):4069-4083.

44. Gobel M, Kranz OH, Kaschabek SR, Schmidt E, Pieper DH, Reineke W: Microorganisms degrading chlorobenzene via a meta-cleavage pathway harbor highly similar chlorocatechol 2,3-dioxygenase-encoding gene clusters. Arch Microbiol 2004, 182:147-156.

45. Tarao M, Seto M: Estimation of the yield coefficient of Pseudomonas sp. strain DP-4 with a low substrate (2,4-dichlorophenol [DCP]) concentration in a mineral medium from which uncharacterized organic compounds were eliminated by a non-DCP-degrading organism. Appl Environ Microbiol 2000, 66:566-570

46. Goswami M, Shivaraman N, Singh RP: Kinetics of chlorophenol degradation by benzoate-induced culture of Rhodococcus erythropolis M1. World J Microbiol Biotechnol 2002, 18:779-783.

47. Tyler JE, Finn RK: Growth rates of a Pseudomonad on 2,4-D and 2,4 dichlorophenol. App/ Microbio/ 1974, 28:181-184

48. Wang CC, Lee CM, Kuan CH: Removal of 2,4-dichlorophenol by suspended and immobilized Bacillus insolitus. Chemosphere 2000, 41(3):447-452.

49. Fukumori F, Hausinger RP: Purification and characterization of 2,4-dichlorophenoxyacetate/alpha-ketoglutarate dioxygenase. J BiO Chem 1993, 268(32):24311-243117.

50. Perkins EJ, Gordon MP, Caceres O, Lurquin PF: Organization and sequence analysis of the 2,4-dichlorophenol hydroxylase and dichlorocatechol oxidative operons of plasmid pJP4. J Bacteriol 1990, 172(5):2351-2359.

51. Koh S, McCullar MV, Focht DD: Biodegradation of 2,4-dichlorophenol through a distal meta-fission pathway. Appl Environ Microbiol 1997, 63(5):2054-2057. 
52. Li DY, Eberspacher J, Wagner B, Kuntzer J, Lingens F: Degradation of 2,4,6trichlorophenol by Azotobacter sp. strain GP1. Appl Environ Microbiol 1991, 57:1920-1928

53. Kiyohara H, Hatta T, Ogawa Y, Kakuda T, Yokoyama H, Takizawa N: Isolation of Pseudomonas pickettii strains that degrade 2,4,6-trichlorophenol and their dechlorination of chlorophenols. Appl Environ Microbiol 1992, 58:1276-1283

54. Matus V, Sanchez MA, Martinez M, Gonzalez B: Efficient degradation of 2,4,6-trichlorophenol requires a set of catabolic genes related to tcp genes from Ralstonia eutropha JMP134(pJP4). Appl Environ Microbiol 2003, 69:7108-7115.

55. Xun LY, Webster CM: A monooxygenase catalyzes sequential dechlorinations of 2,4,6-trichlorophenol by oxidative and hydrolytic reactions. J Biol Chem 2004, 279:6696-6700

56. Mannisto MK, Tiirola MA, Salkinoja-Salonen MS, Kulomaa MS, Puhakka JA: Diversity of chlorophenol degrading bacteria isolated from contaminated borealgroundwater. Arch Microbiol 1999, 171:189-197.

57. Tiirola MA, Busse HJ, Kampfer P, Mannisto MK: Novosphingobium lentum sp nov., a psychrotolerant bacterium from a polychlorophenol bioremediation process. Int J Syst Evol Microbiol 2005, 55:583-588.

58. Louie TM, Webster CM, Xun L: Genetic and biochemical characterization of a 2,4,6-trichlorophenol degradation pathway in Ralstonia eutropha JMP134. J Bacteriol 2002, 184(13):3492-3500.

59. Coenye T, Henry D, Speert DP, Vandamme P: Burkholderia phenoliruptrix sp. nov., to accommodate the 2,4,5-trichlorophenoxyacetic acid and halophenol-degrading strain AC1100. Syst Appl Microbiol 2004, 27(6):623-627.

60. Webb BN, Ballinger JW, Kim E, Belchik SM, Lam KS, Youn B, Nissen MS, Xun $L$, Kang C: Characterization of chlorophenol 4-monooxygenase (TftD) and NADH:FAD oxidoreductase (TftC) of Burkholderia cepacia AC1100. J Biol Chem 2010, 285(3):2014-2027.

61. Gisi MR, Xun L: Characterization of chlorophenol 4-monooxygenase (TftD) and NADH: flavin adenine dinucleotide oxidoreductase (TfC) of Burkholderia cepacia AC1100. J Bacteriol 2009, 185(9):2786-2792.

62. Zaborina O, Daubaras DL, Zago A, Xun L, Saido K, Klem T, Nikolic D, Chakrabarty AM: Novel pathway for conversion of chlorohydroxyquinol to maleylacetate in Burkholderia cepacia AC1100. J Bacteriol 1998, 180(17):4667-4675.

63. Ohtsubo Y, Miyauchi K, Kanda K, Hatta T, Kiyohara H, Senda T, Nagata Y, Mitsui $Y$, Takagi M: PcpA, which is involved in the degradation of pentachlorophenol in Sphingomonas chlorophenolica ATCC39723, is a novel type of ring-cleavage dioxygenase. FEBS Lett 1999, 459(3):395-398.

64. Lange CC, Schneider BJ, Orser CS: Verification of the role of PCP 4-monooxygenase in chlorine elimination from pentachlorophenol by Flavobacterium sp. strain ATCC 39723. Biochem Biophys Res Commun 1996, 219(1):146-149.

65. Orser CS, Lange CC: Molecular analysis of pentachlorophenol degradation. Biodegradation 1994, 5:277-288.

66. Uotila JS, Salkinoja-Salonen MS, Apajalahti JHA: Dechlorination of pentachlorophenol by membrane boundenzymes of Rhodococcus chlorophenolicus PCP-I. Biodegradation 1991, 2:25-31.

67. Uotila JS, Kitunen VH, Saastamoinen T, Coote T, Haggblom MM, Salkinoja-Salonen MS: Characterization of aromatic dehalogenases of Mycobacterium fortuitum CG-2. J Bacteriol 1992, 174:5669-5675.

68. Apajalahti JHA, Salkinoja-Salonen MS: Complete dechlorination of tetrachlorohydroquinone by cell-extracts of pentachlorophenol-induced Rhodococcus chlorophenolicus. J Bacteriol 1987, 169:5125-5130.

69. Arora PK, Jain RK: Pathway for degradation of 2-chloro-4-nitrophenol by Arthrobacter sp. SJCon. Curr Microbiol 2011, 63:568-573.

70. Ghosh A, Khurana M, Chauhan A, Takeo M, Chakraborti AK, Jain RK: Degradation of 4-nitrophenol, 2-chloro-4-nitrophenol, and 2,4-dinitrophenol by Rhodococcus imtechensis strain RKJ300. Environ Sci Technol 2010, 44:1069-1077.

71. Bruhn C, Bayly RC, Knackmuss HJ: The Invivo construction of 4-chloro-2-nitrophenol assimilatory bacteria. Arch Microbiol 1988, 150:171-177.

72. Beunink J, Rehm HJ: Coupled reductive and oxidative degradation of 4-chloro-2-nitrophenol by a co-immobilized mixed culture system. Appl Microbiol Biotechnol 1990, 34:108-115.

73. Arora PK, Jain RK: Biotransformation of 4-chloro-2-nitrophenol into 5-chloro-2. methylbenzoxazole by a marine Bacillus sp. strain MW-1. Biodegradation 2012, 23:325-331.
74. Arora PK: Decolourization of 4-chloro-2-nitrophenol by a soil bacterium, Bacillus subtilis RKJ 700. PLoS One 2012, 7:e52012.

75. Schenzle A, Lenke H, Spain JC, Knackmuss HJ: Chemoselective nitro group reduction and reductive dechlorination initiate degradation of 2 chloro-5-nitrophenol by Ralstonia eutropha JMP134. App/ Environ Microbiol 1999, 65:2317-2323.

76. Pandey J, Sharma NK, Khan F, Ghosh A, Oakeshott JG, Jain RK, Pandey G: Chemotaxis of Burkholderia sp. strain SJ98 towards chloronitroaromatic compounds that it can metabolise. BMC Microbiol 2010, 12:19.

77. Lechner U, Baumbach R, Becker D, Kitunen V, Auling G, Salkinoja-Salonen M: Degradation of 4-chloro-2-methylphenol by an activated sludge isolate and its taxonomic description. Biodegradation 1995, 6(2):83-92.

78. Mikesell MD, Boyd SA: Complete reductive dechlorination and mineralization of pentachlorophenol by anaerobic microorganisms. Appl Environ Microbiol 1986, 52:861-865

79. Londry KL, Fedorak PM: Benzoic-acid intermediates in the anaerobic biodegradation of phenols. Can J Microbiol 1992, 38:1-11.

80. Yang S, Shibata A, Yoshida N, Katayama A: Anaerobic mineralization of pentachlorophenol (PCP) by combining PCP-dechlorinating and phenol-degrading cultures. Biotechnol Bioeng 2009, 102(1):81-90.

81. Becker JG, Stahl DA, Rittmann BE: Reductive dehalogenation and conversion of 2-chlorophenol to 3-chlorobenzoate in a methanogenic sediment community:Implications for predicting the environmental fate of chlorinated pollutants. Appl Environ Microbiol 1999, 65:5169-5172.

82. Boyd SA, Shelton DR: Anaerobic biodegradation of chlorophenols in fresh and acclimated sludge. Appl Environ Microbiol 1984, 47:272-277.

83. Nicholson DK, Woods SL, Istok JD, Peek DC: Reductive dechlorination of chlorophenols by a pentachlorophenolacclimated methanogenic consortium. Appl Environ Microbiol 1992, 58:2280-2286.

84. Madsen T, Aamand $\mathrm{H}$ : Anaerobic transformation and toxicity of trichlorophenols in a stable enrichment culture. Appl Environ Microbiol 1992, 58(2):557-561.

85. Wang YT, Muthukrishnan S, Wang ZM: Reductive dechlorination of chlorophenols in methanogenic cultures. J Environ Eng-ASCE 1998, 124:231-238.

86. Takeuchi R, Suwa Y, Yamagishi T, Yonezawa $Y$ : Anaerobic transformation of chlorophenols in methanogenic sludge unexposed to chlorophenols. Chemosphere 2000, 41:1457-1462

87. Zhang X, Wiegel J: Sequential anaerobic degradation of 24 dichlorophenol in freshwater sediments. Appl Environ Microbiol 1990 56:1119-1127

88. Häggblom MM, Young LY: Chlorophenol degradation coupled to sulfate reduction. Appl Environ Microbiol 1990, 56(11):3255-3260.

89. Haggblom MM, Young LY: Anaerobic degradation of halogenated phenols by sulfate-reducing consortia. Appl Environ Microbiol 1995 61:1546-1550

90. Häggblom MM, Rivera MD, Young LY: Influence of alternative electron acceptors on the anaerobic biodegradability of chlorinated phenols and benzoic acids. App/ Environ Microbiol 1993, 59(4):1162-1167.

91. Bae HS, Yamagishi T, Suwa Y: Evidence for degradation of 2-chlorophenol by enrichment cultures under denitrifying conditions. Microbiology 2002, 148:221-227.

92. Sanford RA, Tiedje JM: Chlorophenol dechlorination and subsequent degradation in denitrifying microcosms fed low concentrations of nitrate. Biodegradation 1997, 7:425-434.

93. Kazumi J, Haggblom MM, Young LY: Degradation of monochlorinated and nonchlorinated aromatic-compounds under iron-reducing conditions. Appl Environ Microbiol 1995, 61:4069-4073.

94. Yu HY, Wang YK, Chen PC, Li FB, Chen MJ, Hu M, Ouyang X: Effect of nitrate addition on reductive transformation of pentachlorophenol in paddy soil in relation to iron(III) reduction. J Environ Manage 2013, 132C:42-48

95. Itoh K, Mihara Y, Tanimoto N, Shimada T, Suyama K: Reductive dechlorination of chlorophenols in estuarine sediments of Lake Shinji and Lake Nakaumi. J Environ Sci Health B 2010, 45(5):399-407.

96. Itoh K, Mihara Y, Toshima Y, Suyama K: Characterization of microbial consortia that reductively dechlorinate 4-chlorophenol and transform phenol to benzoate enriched from estuarine sediment of Lake Shinji. J Environ Sci Health B 2011, 46(2):181-190.

97. Li Z, Inoue Y, Suzuki D, Ye L, Katayama A: Long-term anaerobic mineralization of pentachlorophenol in a continuous-flow system using 
only lactate as an external nutrient. Environ Sci Technol 2013, 47(3):1534-1541.

98. Villemur R: The pentachlorophenol-dehalogenating Desulfitobacterium hafniense strain PCP-1. Philos Trans R Soc B 2013, 368:20120319.

99. Christiansen N, Ahring BK: Desulfitobacterium hafniense sp nov, an anaerobic, reductively dechlorinating bacterium. Int J Syst Bacterio/ 1996, 46:442-448

100. Mohn WW, Kennedy KJ: Reductive dehalogenation of chlorophenols by Desulfomonile tiedjei DCB-1. Appl Environ Microbiol 1992, 58(4):1367-1370.

101. Sanford RA, Cole JR, Tiedje JM: Characterization and description of Anaeromyxobacter dehalogenans gen. nov., sp. nov., an aryl-halorespiring facultative anaerobic myxobacterium. Appl Environ Microbiol 2002, 68(2):893-900

102. Utkin I, Woese C, Wiegel J: Isolation and characterization of Desulfitobacterium dehalogenans gen. nov, sp. nov, an anaerobic bacterium which reductively dechlorinates chlorophenolic compounds. Int J Syst Bacteriol 1994, 44:612-619.

103. Sanford RA, Cole JR, Loffler FE, Tiedje JN: Characterization of Desulfitobacterium chlororespirans sp nov, which grows by coupling the oxidation of lactate to the reductive dechlorination of 3-chloro-4-hydroxybenzoate. Appl Environ Microbiol 1996, 62:3800-3808.

104. He Q, Sanford RA: Induction characteristics of reductive dehalogenation in the ortho-halophenol-respiring bacterium. Anaeromyxobacter dehalogenans. Biodegradation 2002, 13(5):307-316.

105. Wang S, Zhang W, Yang KL, He J: Isolation and characterization of a novel Dehalobacter species strain TCP1 that reductively dechlorinates 2,4,6trichlorophenol. Biodegradation 2013. doi:10.1007/s10532-013-9662-1.

106. Don RH, Weightman AJ, Knackmuss HJ, Timmis KN: Transposon mutagenesis and cloning analysis of the pathways for degradation of 2,4-dichlorophenoxyacetic acid and 3-chlorobenzoate in Alcaligenes eutrophus JMP134(pJP4). J Bacteriol 1995, 161(1):85-90.

107. Sánchez MA, González B: Genetic characterization of 2, 4, 6trichlorophenol degradation in Cupriavidus necator JMP134. Appl Environ Microbiol 2007, 73(9):2769-2776.

108. Chatterjee DK, Kellogg ST, Hamada S, Chakrabarty AM: Plasmid specifying total degradation of 3-chlorobenzoate by a modified ortho pathway. J Bacteriol 1981, 146(2):639-646

109. van der Meer JR, van Neerven AR, de Vries EJ, de Vos WM, Zehnder AJ: Cloning and characterization of plasmid-encoded genes for the degradation of 1,2-dichloro-, 1,4-dichloro-, and 1,2,4-trichlorobenzene of Pseudomonas sp. strain P51. J Bacteriol 1991, 173(1):6-15.

110. Hatta T, Fujii E, Takizawa N: Analysis of two gene clusters involved in 2,4,6-trichlorophenol degradation by Ralstonia pickettii DTP0602. Biosci Biotechnol Biochem 2012, 76:892-899.

111. Torii $H$, Machida A, Hara $H$, Hatta $T$, Takizawa $N$ : The regulatory mechanism of 2,4,6-trichlorophenol catabolic operon expression by HadR in Ralstonia pickettii DTP0602. Microbiology 2013, 159:665-677.

112. Cámara B, Nikodem P, Bielecki P, Bobadilla R, Junca H, Pieper DH: Characterization of a gene cluster involved in 4-chlorocatechol degradation by Pseudomonas reinekei MT1. J Bacteriol 2009, 191(15):4905-4915.

113. Hubner A, Danganan CE, Xun L, Chakrabarty AM, Hendrickson W: Genes for 2,4,5-trichlorophenoxyacetic acid metabolism in Burkholderia cepacia $\mathrm{AC}$ 1100: characterization of the $\mathrm{tftC}$ and $\mathrm{ttD}$ genes and locations of the tft operons on multiple replicons. Appl Environ Microbio/ 1998, 64:2086-2093.

114. Danganan CE, Ye RW, Daubaras DL, Xun L, Chakrabarty AM: Nucleotide sequence and functional analysis of the genes encoding 2,4,5trichlorophenoxyacetic acid oxygenase in Pseudomonas cepacia AC1100. Appl Environ Microbiol 1994, 60:4100-4106

115. Daubaras DL, Hershberger CD, Kitano K, Chakrabarty AM: Sequence analysis of a gene cluster involved in metabolism of 2,4,5-trichlorophenoxyacetic acid by Burkholderia cepacia AC1100. Appl Environ Microbiol 1995, 61:1279-1289.

116. Cai M, Xun L: Organization and regulation of pentachlorophenoldegrading genes in Sphingobium chlorophenolicum ATCC 39723. J Bacteriol 2002, 184(17):4672-4680.

117. Xun L, Topp E, Orser CS: Diverse substrate range of a Flavobacterium pentachlorophenol hydroxylase and reaction stoichiometries. J Bacteriol 1992, 174:2898-2902.

118. Karlson U, Rojo F, vanElsas JD, Moore E: Genetic and serological evidence for the recognition of four pentachlorophenol degrading bacterial strains as a species of the genus Sphingomonas. Syst App/ Microbiol 1996, 18:539-548.

119. Ederer MM, Crawford RL, Herwig RP, Orser CS: PCP degradation is mediated by closely related strains of the genus Sphingomonas. Mol Ecol 1997, 6:39-49.

120. Cassidy MB, Lee H, Trevors JT, Zablotowicz RB: Chlorophenol and nitrophenol metabolism by Sphingomonas sp. UG30. J Ind Microbiol Biotechnol 1999, 23:232-241.

121. Leung KT, Campbell S, Gan Y, White DC, Lee H, Trevors JT: The role of the Sphingomonas species UG30 pentachlorophenol-4-monooxygenase in p-nitrophenol degradation. FEMS Microbiol Lett 1999, 173:247-253.

122. Leung KT, Cassidy MB, Shaw KW, Lee H, Trevors JT, Lohmeier-Vogel EM, Vogel HJ: Pentachlorophenol biodegradation by Pseudomonas spp. UG25 and UG30. World J Microbiol Biotechnol 1997, 13:305-313.

123. Tiirola MA, Mannisto MK, Puhakka JA, Kulomaa MS: Isolation and characterization of Novosphingobium sp. strain MT1, a dominant polychlorophenol-degrading strain in a groundwater bioremediation system. Appl Environ Microbiol 2002, 68:173-180.

124. Saboo VM, Gealt MA: Gene sequences of the $p c p B$ gene of pentachlorophenol-degrading Sphingomonas chlorophenolica found in non degrading bacteria. Can J Microbiol 1998, 44:667-675.

125. Smidt H, van Leest M, van der Oost J, de Vos WM: Transcriptional regulation of the cpr gene cluster in ortho-chlorophenol-respiring Desulfitobacterium dehalogenans. J Bacteriol 2000, 182:5683-5691.

126. Villemur R, Lanthier M, Beaudet R, Le'pine F: The Desulfitobacterium genus. FEMS Microbiol Rev 2006, 30:706-733.

127. Smidt $H$, van Leest $M$, van der Oost J, de Vos WM: Transcriptional regulation of the cpr gene cluster in ortho-chlorophenol-respiring Desulfitobacterium dehalogenans. J Bacteriol 2000, 182(20):5683-5691.

128. Gábor K, Veríssimo CS, Cyran BC, Ter Horst P, Meijer NP, Smidt H, de Vos WM, van der Oost J: Characterization of CprK1, a CRP/FNR-type transcriptional regulator of halorespiration from Desulfitobacterium hafniense. J Bacterio/ 2006, 188(7):2604-2613.

129. Gauthier A, Beaudet R, Le'pine F, Juteau P, Villemur R: Occurrence and expression of $c r d \mathrm{~A}$ and $c p r A 5$ encoding chloroaromatic reductive dehalogenases in Desulfitobacterium strains. Can J Microbiol 2006, 52:47-55.

130. van de Pas BA, Smidt H, Hagen WR, van der Oost J, Schraa G, Stams AJM, de Vos WM: Purification and molecular characterization of orthochlorophenol reductive dehalogenase, a key enzyme of halorespiration in Desulfitobacterium dehalogenans. J Biol Chem 1999, 274:20287-20292.

131. Bisaillon A, Beaudet R, Le'pine F, Deziel E, Villemur R: Identification and characterization of a novel CprA reductive dehalogenase specific to highly chlorinated phenols from Desulfitobacterium hafniense strain PCP-1. Appl Environ Microbiol 2010, 76:7536-7540.

132. Thibodeau J, Gauthier A, Duguay M, Villemur R, Le'pine F, Juteau P, Beaudet $R$ : Purification, cloning, and sequencing of a 3,5-dichlorophenol reductive dehalogenase from Desulfitobacterium frappieri PCP-1. Appl Environ Microbiol 2004, 70:4532-4537.

133. Bisaillon A, Beaudet R, Le'pine F, Villemur R: Quantitative analysis of the relative transcript levels of four chlorophenol reductive dehalogenase genes in Desulfitobacterium hafniense PCP-exposed to chlorophenols. Appl Environ Microbiol 2011, 77:6261-6264.

134. Boyer A, Page'-Be'langer R, Saucier M, Villemur R, Le'pine F, Juteau P, Beaudet R: Purification, cloning and sequencing of an enzyme mediating the reductive dechlorination of 2,4,6-trichlorophenol from Desulfitobacterium frappieri PCP-1. Biochem J 2003, 373:297-303.

doi:10.1186/1475-2859-13-31

Cite this article as: Arora and Bae: Bacterial degradation of chlorophenols and their derivatives. Microbial Cell Factories 2014 13:31. 